\title{
Structure of the 1,4-Bis(2'-deoxyadenosin-No-yl)-2S,3S-butanediol Intra-strand DNA Cross-link Arising from Butadiene Diepoxide in the Human N-ras Codon 61 Sequence
}

\author{
Wen Xu, W. Keither Merritt $\S$, Lubomir V. Nechev $\llbracket$, Thomas M. Harris, Constance M. Harris, \\ R. Stephen Lloyd $\ddagger$, and Michael P. Stone \\ Department of Chemistry, Center in Molecular Toxicology, Vanderbilt-Ingram Cancer Center, \\ Vanderbilt University, Nashville, Tennessee 37235
}

\begin{abstract}
The 1,4-bis( $2^{\prime}$-deoxyadenosin- $N^{6}$-yl)-2S,3S-butanediol intra-strand DNA cross-link arises from bisalkylation of tandem $N^{6}$-dA sites in DNA by $R, R$-butadiene diepoxide $\left(\mathrm{BDO}_{2}\right)$. The oligodeoxynucleotide $5^{\prime}-\mathrm{d}\left(\mathrm{C}^{1} \mathrm{G}^{2} \mathrm{G}^{3} \mathrm{~A}^{4} \underline{\mathrm{C}}^{\underline{5}} \underline{\underline{X}} \underline{\underline{6}} \underline{\mathrm{Y}^{7}} \mathrm{G}^{8} \mathrm{~A}^{9} \mathrm{~A}^{10} \mathrm{G}^{11}\right)-3^{\prime} \cdot 5^{\prime}-\mathrm{d}$ $\left(\mathrm{C}^{12} \mathrm{~T}^{13} \mathrm{~T}^{14} \mathrm{C}^{15} \mathrm{~T}^{16} \mathrm{~T}^{17} \mathrm{G}^{18} \mathrm{~T}^{19} \mathrm{C}^{20} \mathrm{C}^{21} \mathrm{G}^{22}\right)-3^{\prime}$ contains the $\mathrm{BDO}_{2}$ cross-link between the second and third adenines of the codon 61 sequence (underlined) of the human $\mathrm{N}$-ras protooncogene and is named the $(S, S)$-BD-(61-2,3) cross-link ( $\mathrm{X}, \mathrm{Y}=$ cross-linked adenines). NMR analysis reveals that the cross-link is oriented in the major groove of duplex DNA. Watson-Crick base pairing is perturbed at base pair $\mathrm{X}^{6} \cdot \mathrm{T}^{17}$, whereas base pairing is intact at base pair $\mathrm{Y}^{7} \cdot \mathrm{T}^{16}$. The cross-link appears to exist in two conformations, in rapid exchange on the NMR time scale. In the first conformation, the $\beta-\mathrm{OH}$ is predicted to form a hydrogen bond with $\mathrm{T}^{16} O^{4}$, whereas in the second, the $\beta-\mathrm{OH}$ is predicted to form a hydrogen bond with $\mathrm{T}^{17} O^{4}$. In contrast to the $(R, R)$-BD-(61-2,3) cross-link in the same sequence [Merritt, W.K., Nechev, L.V., Scholdberg, T.A., Dean, S.M., Kiehna, S.E., Chang, J.C., Harris, T.M., Harris, C.M., Lloyd, R.S., and Stone, M.P. (2005) Biochemistry 44, 10081-10092], the anti conformation of the two hydroxyl groups at $\mathrm{C}_{\beta}$ and $\mathrm{C}_{\gamma}$ with respect to the $\mathrm{C}_{\beta}-\mathrm{C}_{\gamma}$ bond results in a decreased twist between base pairs $\mathrm{X}^{6} \cdot \mathrm{T}^{17}$ and $\mathrm{Y}^{7} \cdot \mathrm{T}^{16}$, and an approximate $10^{\circ}$ bending of the duplex. These conformational differences may account for the differential mutagenicity of the $(S, S)$ - and $(R, R)$-BD-(61-2,3) cross-links, and suggest that stereochemistry plays a role in modulating biological responses to these cross-links [Kanuri, M., Nechev, L. V., Tamura, P. J., Harris, C. M., Harris, T. M., and Lloyd, R. S. (2002) Chem. Res. Toxicol. 15, 1572-1580].
\end{abstract}

\footnotetext{
*Author to whom correspondence should be addressed. Telephone 615-322-2589; FAX 615-322-7591; email michael.p.stone@vanderbilt.edu.

${ }^{\S}$ Current Address for W. Keither Merritt: National Institute of Environmental Health Sciences, National Institutes of Health, Department of Health and Human Services, P.O. Box 12233, Research Triangle Park, NC 27709

TI Current Address for Lubomir Nechev: Alnylam Pharmaceuticals, 790 Memorial Drive Suite 202, Cambridge, MA 02139

₹Center for Research in Occupational and Environmental Toxicology, Oregon Health and Science University, 3181 SW Sam Jackson Park Road, L606, Portland, Oregon 97239-3098

${ }^{\dagger}$ This work was supported by NIH grant ES-05509 (M.P.S). Funding for the NMR spectrometers was supplied by Vanderbilt University; by NIH grant RR-05805, and the Vanderbilt Center in Molecular Toxicology, ES-00267. The Vanderbilt-Ingram Cancer Center is supported by NIH grant CA-68485.

${ }^{1}$ Abbreviations: BD, butadiene; BDO, butadiene monoepoxide (1,2-epoxy-3-butene); $\mathrm{BDO}_{2}$, butadiene diepoxide (1,2:3,4diepoxybutane); BDE, 3,4-dihydroxy-1,2-epoxybutanes; SBR, styrene-butadiene rubber; MALDI-TOF, matrix assisted laser desorption ionization time-of-flight; TOCSY, total correlation spectroscopy, DQF-COSY, double-quantum filtered correlation spectroscopy; TPPI, time-proportional phase increment; CORMA, complete relaxation matrix analysis; rMD, restrained molecular dynamics; rmsd, root mean square deviation; $\mathrm{R}_{1}{ }^{\mathrm{X}}$, sixth root residual.

${ }^{2}$ The definitions of the prochiral protons $\mathrm{C}_{\alpha}$ and $\mathrm{C}_{\delta}$ of the $N^{6}, N^{6}$-dA cross-link are based upon the Cahn, Ingold and Prelog nomenclature. The proton $\mathrm{H}_{\alpha}$ is defined as the pro- $R$ proton at $\mathrm{C}_{\alpha} ; \mathrm{H}_{\alpha}$ is defined as the pro- $S$ proton at $\mathrm{C}_{\alpha}$. Likewise, $\mathrm{H}_{\delta}$ is the pro- $R$ proton at $\mathrm{C}_{\alpha}$; $\mathrm{H}_{\delta^{\prime}}$ is the pro- $S$ proton at $\mathrm{C}_{\delta}$.
} 


\section{Introduction}

1,3-Butadiene (CAS RN 106-99-0) (BD) ${ }^{\mathrm{i}}$ is used in the manufacture of styrene-butadiene rubber (SBR) (1,2); several billion lbs/yr are produced in the United States. It is a combustion product from automobile emissions (3) and cigarette smoke (4). BD is genotoxic and is a carcinogen in rodents, particularly in mice (5-7) and also in rats (8). BD is classified by the United States Environmental Protection Agency as "carcinogenic to humans by inhalation" (9). The International Agency for Cancer Research (IARC) lists BD as a "probable human carcinogen" (Group 2A) (10-12). Chronic human exposure in the SBR industry may induce genotoxic effects (13-15) and is correlated with increased risk for leukemia $(1,16-$ 24).

$\mathrm{BD}$ is epoxidized primarily by cytochrome $\mathrm{P} 4502 \mathrm{E} 1$, but also by cytochrome $\mathrm{P} 4502 \mathrm{~A} 6$, to form 1,2-epoxy-3-butenes (BDO) (Scheme 1) $(25,26)$. These may be further oxidized by cytochrome P450 2E1 or $3 \mathrm{~A} 4$ to form 1,2:3,4-diepoxybutanes $\left(\mathrm{BDO}_{2}\right)(25,27-31)$. Hydrolysis of BDO mediated by epoxide hydrolase forms 1,2-dihydroxy-3-butenes $(29,32,33)$, which are metabolized by cytochrome $\mathrm{P} 450$ to hydroxymethylvinylketone (HMVK) (34). Either $\mathrm{BDO}_{2}$ or the 1,2-dihydroxy-3-butenes may undergo cytochrome P450-mediated oxidation to form 1,2-dihydroxy-3,4-epoxybutanes (BDE) $(29,32,35)$. Thus, proximate electrophiles arising from $\mathrm{BD}$ metabolism include $\mathrm{BDO}, \mathrm{BDO}_{2}$, and $\mathrm{BDE}$, and potentially, $\mathrm{HMVK}(36)$.

All three optical isomers of $\mathrm{BDO}_{2}$ are genotoxic $(2,10,37)$, and $S, S-\mathrm{BDO}_{2}$ is the most cytotoxic and genotoxic $(38,39)$; it is believed to be the active form of the anti-tumor agent $\mathrm{L}$-threitol-1,4bismethanesulfonate (treosulfan) (40-42). The genotoxicity is probably due to its potential to form DNA-DNA (43-46) and DNA-protein cross-links $(47,48)$, the latter having been observed in mice $(49,50)$. Mice possess greater sensitivity to butadiene exposure than rats, and this is attributed to their efficient oxidation of $\mathrm{BD}$ to $\mathrm{BDO}_{2}(51,52)$, presumably facilitating DNA cross-linking. Butadiene genotoxicity is further enhanced in knockout mice lacking a functional microsomal epoxide hydrolase gene (53). Polymorphisms in the human epoxide hydrolase gene may also contribute to differences in BD genotoxicty within the human population $(54,55)$.

The predominant DNA cross-link induced by $\mathrm{BDO}_{2}$, isolated from DNA and characterized by mass spectrometry (46), involves inter-strand bis-alkylation at N7-dG, particularly in 5'GNC-3' sequences (45). The formation of N7,N7-dG cross-links is dependent upon stereochemistry of the $\mathrm{BDO}_{2}$; with $S, S \mathrm{BDO}_{2}>R, R \mathrm{BDO}_{2}>$ meso $\mathrm{BDO}_{2}(56,57)$. Treatment of DNA with meso $\mathrm{BDO}_{2}$ yields comparable numbers of 1,2-intra-strand and 1,3-inter-strand bis-N7-dG cross-links, while $S, S \mathrm{BDO}_{2}$ produces few intra-strand cross-links. Treatment of DNA with $R, R-\mathrm{BDO}_{2}$ yields mostly 1,3-interstrand bis-N7-dG cross-links, with smaller amounts of 1,2-interstrand and 1,2-intrastrand cross-links. The differential cross-linking specificities of $\mathrm{BDO}_{2}$ stereoisomers may be related to the differential relative configurations of the hydroxyl and remaining oxirane groups in the mono-adducted N7-dG intermediate, with differential hydrogen bonding interactions involving the hydroxyl group mediating the consequent orientation of the oxirane in the major groove (56). Ultimately, these structural differences may be related to biological processing (56).

The structural characterization of bis-N7-dG cross-links remains elusive, in part because N7$\mathrm{dG}$ alkylation products are chemically unstable. In contrast, the synthetically accessible and stable $N^{6}, N^{6}$-dA intra-strand cross-links (58) provide a model system with which to probe the role of hydroxyl stereochemistry in modulating the structure of $\mathrm{BDO}_{2}$-induced cross-links in the major groove of DNA, and their consequent biological processing. With regard to occurrence in DNA, asymmetrical $N^{6}$-dA:N7-dG but not $N^{6}, N^{6}$-dA cross-links are 
characterized; the $N^{6}$-dA:N7-dG cross-links are less abundant than are bis-N7-dG cross-links, but may contribute to butadiene genotoxicty (59). The prevailing hypothesis posits that the less abundant $N^{6}$ alkylation products of butadiene epoxides result from initial alkylation at the N1 position, followed by Dimroth rearrangement $(60,61)$. This probably explains why $N^{6}, N^{6}$-dA intra-strand cross-links occur infrequently in duplex DNA (N. Tretyakova, personal communication). However, the BDT N1-dA mono adduct was identified in humans exposed occupationally to BD (62), and the $N^{6}$-dA BDT mono adduct was identified in Chinese Hamster ovary cells (63), suggesting that $N^{6}, N^{6}$-dA intra-strand cross-links might form in duplex DNA, albeit at low levels.

Replication of DNAs containing the 1,4-bis(2'-deoxyadenosin- $N^{6}$-yl)-2R,3R-butanediol crosslink in COS-7 cells yields 59\% of single base substitutions at the $3^{\prime}$ adducted base, while $19 \%$ mutagenesis is detected using the 1,4-bis( $2^{\prime}$-deoxyadenosin- $N^{6}$-yl)-2S,3S-butanediol crosslink. The primary mutations are $\mathrm{A} \rightarrow \mathrm{G}$ transitions observed at the $3^{\prime}$ adenine of the cross-link. However, the level of mutations observed in the COS-7 cells is greater than is observed in the bacterial cells. Because $N^{6}, N^{6}$-dA cross-links (58) are significantly more mutagenic than are $N^{6}$-dA monoadducts arising from $\mathrm{BDO}$ or $\mathrm{BDE}(64,65)$, their potential as rare but biologically significant lesions cannot be discounted.

Since both of the stereoisomeric cross-links are readily replicated by COS-7 cells (58), it was proposed that these cross-links are accommodated within the major groove, similar to several $N^{6}$-dA adducts of styrene oxide, which also are readily replicated in site-specific mutagenesis experiments $(66,67)$. This is in contrast to the corresponding $N^{2}, N^{2}-\mathrm{dG}(R, R)$ and $(S, S)$ intrastrand cross-links, which are severe replication blocks to cells (68). The structure of the 1,4-bis(2'-deoxyadenosin- $\mathrm{N}^{6}$-yl)-2R,3R-butanediol cross-link, the $(R, R)$-BD-(61-2,3) crosslink, which arises from $S, S-\mathrm{BDO}_{2}$, in the oligodeoxynucleotide 5'-d(CGGACXYGAAG)-3' $\cdot 5^{\prime}$-d(CTTCTTGTCCG)-3' (X,Y = cross-linked adenines) (69) confirms that the cross-linked moiety is accommodated in the major groove of the DNA. Watson-Crick base pairing is disrupted at position $X^{6} \cdot T^{17}$, the $5^{\prime}$-side of the intrastrand cross-link. Helicoidal analysis suggests an opening of this base pair. A proposed hydrogen bond between the $\beta$-hydroxyl group of the cross-link, and $\mathrm{T}^{17} \mathrm{O}^{4}$, the nucleotide complementary to $\mathrm{X}^{6}$, shields the $\mathrm{T}^{17}$ imino hydrogen from exchange with solvent. In contrast, Watson-Crick base pairing is intact at position $\mathrm{Y}^{7} \cdot \mathrm{T}^{16}$, the $3^{\prime}$-side of the cross-link.

Presently, we report that the 1,4-bis( $2^{\prime}$-deoxyadenosin- $N^{6}$-yl)-2S,3S-butanediol cross-link, the $(S, S)$-BD-(61-2,3) cross-link, which arises from $R, R$ - $\mathrm{BDO}_{2}$, is also oriented in the major groove of duplex DNA. Watson-Crick base pairing is perturbed at base pair $\mathrm{X}^{6} \cdot \mathrm{T}^{17}$, whereas base pairing is intact at base pair $\mathrm{Y}^{7} \cdot \mathrm{T}^{16}$. The major conformational difference as compared to the $(R, R)$-BD-(61-2,3) cross-link (69) regards the conformation of the four-carbon butadiene chain. The anti conformation of the two hydroxyl groups at $\mathrm{C}_{\beta}$ and $\mathrm{C}_{\gamma}$ with respect to the $\mathrm{C}_{\beta}$ - $\mathrm{C}_{\gamma}$ bond in the $(S, S)$-BD-(61-2,3) cross-link requires greater structural perturbation to the DNA duplex, resulting in a decreased twist between base pairs $X^{6} \cdot \mathrm{T}^{17}$ and $\mathrm{Y}^{7} \cdot \mathrm{T}^{16}$, and an approximate $10^{\circ}$ bending of the cross-linked duplex. The $(S, S)$-BD-(61-2,3) cross-link appears to exist in two conformations, in rapid exchange on the NMR time scale. The two conformations are predicted to exhibit differential hydrogen bonding involving the $\beta$-OH moiety of the butadiene crosslink. In the first, the $\beta-\mathrm{OH}$ is predicted to form a hydrogen bond with $\mathrm{T}^{16} O^{4}$, whereas in the second conformation, the $\beta-\mathrm{OH}$ is predicted to form a hydrogen bond with $\mathrm{T}^{17} O^{4}$.

\section{Materials and Methods}

\section{Sample Preparation}

The oligodeoxynucleotide 5'-d(CTTCTTGTCCG)-3' was synthesized by the Midland Certified Reagent Co. (Midland, TX) and purified by anion-exchange chromatography. The 
butadiene-cross-linked oligodeoxynucleotide $5^{\prime}$-d(CGGACXYGAAG)-3' was synthesized as described $(58,70)$. The concentrations of the single-stranded oligodeoxynucleotides were determined from the extinction coefficients at $260 \mathrm{~nm}$ (71). The modified oligodeoxynucleotide and its complementary strand were annealed in a buffer solution consisting of $10 \mathrm{mM} \mathrm{NaH}_{2} \mathrm{PO}_{4}, 0.1 \mathrm{M} \mathrm{NaCl}$, and $50 \mu \mathrm{M} \mathrm{Na} 2$ EDTA at $\mathrm{pH}$ 7.0. The annealed duplex DNA was eluted from a column containing DNA Grade Biogel hydroxylapatite (BioRad Laboratories, Richmond, CA) with a gradient from 10 to $200 \mathrm{mM} \mathrm{NaH}_{2} \mathrm{PO}_{4}$ at pH 7.0. It was lyophilized, resuspended in $1 \mathrm{~mL}$ of $\mathrm{H}_{2} \mathrm{O}$, and desalted using Sephadex G-25. In order to determine that both the correct modified and complementary strands were in solution, MALDITOF mass spectra were obtained on a Voyager-DE (PerSeptive Biosystems, Inc.) instrument in negative reflector mode. The matrix used in each of these studies contained $0.5 \mathrm{M} 3$ hydroxypicolinic acid and $0.1 \mathrm{M}$ ammonium citrate. NMR samples were prepared in $10 \mathrm{mM}$ $\mathrm{NaH}_{2} \mathrm{PO}_{4}, 0.1 \mathrm{M} \mathrm{NaCl}$, and $50 \mu \mathrm{M} \mathrm{Na}{ }_{2}$ EDTA at $\mathrm{pH}$ 7.0. For observation of non-exchangeable protons, the samples were exchanged three times with $99.9 \% \mathrm{D}_{2} \mathrm{O}$ and dissolved in $0.5 \mathrm{~mL}$ of $99.99 \% \mathrm{D}_{2} \mathrm{O}$. For observation of exchangeable protons, the samples were dissolved in $0.5 \mathrm{~mL}$ of 9:1 $\mathrm{H}_{2} \mathrm{O} / \mathrm{D}_{2} \mathrm{O}$.

\section{Thermal Melting Experiments}

The melting temperatures were measured on a Varian Cary 4E spectrophotometer at $260 \mathrm{~nm}$ in a buffer consisting of $10 \mathrm{mM}$ sodium phosphate, $50 \mu \mathrm{M} \mathrm{Na}_{2}$ EDTA, and $1 \mathrm{M} \mathrm{NaCl}$ at $\mathrm{pH} 7.0$, at a temperature increasing rate of $1.0^{\circ} \mathrm{C} / \mathrm{min}$ from 10 to $80^{\circ} \mathrm{C}$. The melting temperatures of the unmodified and modified oligodeoxynucleotides were obtained by the midpoints of the melting curves from the first-order derivatives.

\section{Nuclear Magnetic Resonance}

${ }^{1} \mathrm{H}$ NMR spectra were recorded at $600.13 \mathrm{MHz}$ and $800.23 \mathrm{MHz}$. The non-exchangeable protons were monitored at $25^{\circ} \mathrm{C}$; the exchangeable protons were monitored at $10^{\circ} \mathrm{C}$. Chemical shifts were referenced to the water resonance. NMR data were processed using FELIX2000 (Accelyris, Inc., San Diego, CA). NOESY spectra of the non-exchangeable protons were recorded using TPPI phase cycling with mixing times of 150, 200, and $250 \mathrm{~ms}$. These spectra were acquired sequentially without removing the sample from the magnet. Spectra for the exchangeable protons were recorded using a $200 \mathrm{~ms}$ mixing time. These experiments were recorded with 1024 real data points in the $\mathrm{d} 1$ dimension and 2048 real data points in the $\mathrm{d} 2$ dimension. A relaxation delay of $2.0 \mathrm{~s}$ was used. Water suppression was performed using the WATERGATE sequence (72). TOCSY experiments were performed with mixing times of 90 and $150 \mathrm{~ms}$, utilizing the homonuclear Hartman-Hahn transfer with the MLEV17 sequence for mixing. DQF-COSY spectra were zero-filled to give a matrix of $1024 \times 2048$ real points. A skewed sine-bell square apodization function with a $90^{\circ}$ phase shift and a skew factor of 1.0 was used in both dimensions.

\section{Experimental Restraints}

(a) Distance Restraints-Footprints were drawn around cross peaks obtained at a mixing time of $200 \mathrm{~ms}$ using FELIX2000. Identical footprints were transferred and fit to the crosspeaks obtained at the other two mixing times. The intensities of these cross peaks were determined by volume integration. These were combined as necessary with intensities generated from complete relaxation matrix analysis of a starting DNA structure to generate a hybrid intensity matrix (73-75). MARDIGRAS (76-78) was used to iteratively refine the hybrid intensity matrix and to optimize the agreement between the calculated and experimental NOE intensities. Calculations were initated using isotropic correlation times of 2, 3, and $4 \mathrm{~ns}$, and with both IniA and IniB starting structures and the three mixing times, yielding eighteen sets of distances. Analysis of this data yielded the experimental distance restraints used in subsequent restrained 
molecular dynamics calculations, and the corresponding standard deviations for the distance restraints. The distance restraints were divided into five classes, reflecting the confidence level in the experimental data.

(b) Torsion Angle Restraints-Deoxyribose pseudorotation (57) was determined graphically using the sums of ${ }^{3} \mathrm{~J}^{1} \mathrm{H}$ coupling constants (58), measured from DQF-COSY spectra. Discrete $J_{1^{\prime} 2^{\prime \prime}}$ and $J_{1^{\prime} 2^{\prime}}$ couplings were measured from active and passive couplings, respectively, of the H2" (d2) to H1' (d1) spectral region. The data were fit to curves relating the coupling constants to the deoxyribose sugar pseudo rotation angle $(\mathrm{P})$, sugar pucker amplitude $(\phi)$, and the percentage S-type conformation. The sugar pseudo rotation angle and amplitude ranges were converted to the five dihedral angles $v_{0}$ to $v_{4}$. Coupling constants measured from ${ }^{1} \mathrm{H}_{-}^{31} \mathrm{P}$ HMBC spectra were applied (79,80 1991 1991) to the Karplus relationship (81) to determine the backbone dihedral angle $\varepsilon\left(\mathrm{C}^{\prime}-\mathrm{C} 3^{\prime}-\mathrm{O} 3^{\prime}-\mathrm{P}\right)$, related to the $\mathrm{H} 3^{\prime}-\mathrm{C} 3^{\prime}-\mathrm{O} 3^{\prime}-\mathrm{P}$ angle by a $120^{\circ}$ shift. The $\zeta\left(\mathrm{C}^{\prime}-\mathrm{O} 3^{\prime}-\mathrm{P}-\mathrm{O} 5^{\prime}\right)$ backbone angles were calculated from the correlation between $\varepsilon$ and $\zeta$ in B-DNA (60).

\section{Restrained Molecular Dynamics Calculations}

Classical A-DNA and B-DNA were used as reference structures to create starting structures for the refinement (82). The butadiene adduct was constructed at $\mathrm{A}^{6}$ using the BUILDER module of INSIGHT II (Accelrys, Inc., San Diego, CA). A-form and B-form structures of the appropriate sequence were energy-minimized by the conjugate gradients method for 200 iterations using the AMBER 7.0 force field (83) without experimental restraints to give starting IniA and IniB used for the subsequent relaxation matrix analysis and molecular dynamics calculations. The restraint energy function was comprised of terms describing distances and dihedral restraints, both of which were in the form of a standard square-well potential (84). Bond lengths involving hydrogens were fixed with the SHAKE algorithm (85). The generalized Born approach was used to model solvation $(86,87)$. The calculations utilized a salt concentration of $0.2 \mathrm{mM}$. A series of randomly seeded rMD calculations were performed over a time course of $40 \mathrm{ps}$. These used the SANDER module of AMBER 7.0, and the Cornell et al. force field (88), including the Parm94.dat parameter set. Restrained molecular dynamics calculations were performed using AMBER in implicit solvent. The simulated annealing protocol utilized a starting temperature of $25 \mathrm{~K}$. In the first $1 \mathrm{ps}$ the temperature was increased to $600 \mathrm{~K}$ and this target temperature is maintained for $4 \mathrm{ps}$, followed by cooling to $298 \mathrm{~K}$ over $15 \mathrm{ps}$. During the final $20 \mathrm{ps}$ the temperature was reduced to $0 \mathrm{~K}$. Temperature was controlled by coupling the molecules to a temperature bath. The first $1 \mathrm{ps}$ of heating used a coupling of $0.4 \mathrm{ps}$, followed by $4 \mathrm{ps}$ of constant temperature dynamics with a coupling of $1.0 \mathrm{ps}$. In the following $15 \mathrm{ps}$ of cooling, a heat coupling of $1.0 \mathrm{ps}$ was used, followed by a value of $0.5 \mathrm{ps}$ for the next 15 ps. During the final 5 ps of cooling, the coupling was ramped down to $0.01 \mathrm{ps}$. In the first $1 \mathrm{ps}$ of heating, the experimental force constants were amplified by factors that ranged from 0.5 to 1.00 . During the $4 \mathrm{ps}$ of constant temperature dynamics and the first $15 \mathrm{ps}$ of cooling, the amplification factor was increased to 1.75 . In the final $20 \mathrm{ps}$ of cooling, the amplification factor was reduced to a value of 1.00. Structure coordinates extracted from the final 4 ps of each rMD calculation were averaged and energy-minimized for 200 iterations using the conjugate gradient algorithm.

Back-calculation of ${ }^{1} \mathrm{H}$ NOE data was performed using CORMA (v. 4.0) (75). Helicodial parameters were examined using 3DNA (89) and Curves $(90,91)$. 


\section{Results}

\section{Sample Properties}

The duplex oligodeoxynucleotide $5^{\prime}-\mathrm{d}\left(\mathrm{C}^{1} \mathrm{G}^{2} \mathrm{G}^{3} \mathrm{~A}^{4} \underline{\underline{C}} \underline{\underline{5}} \underline{\underline{6}} \underline{\underline{6}} \underline{\underline{7}} \mathrm{q}^{8} \mathrm{~A}^{9} \mathrm{~A}^{10} \mathrm{G}^{11}\right)-3^{\prime} \cdot 5^{\prime}-\mathrm{d}$ $\left(\mathrm{C}^{12} \mathrm{~T}^{13} \mathrm{~T}^{14} \mathrm{C}^{15} \mathrm{~T}^{16} \mathrm{~T}^{17} \mathrm{G}^{18} \mathrm{~T}^{19} \mathrm{C}^{20} \mathrm{C}^{21} \mathrm{G}^{22}\right)-3^{\prime}$ utilized in the present studies contains the coding sequences for codons 60, 61 (underlined), and 62 of the human $N$-ras proto-oncogene, and was engineered to be inserted into bacterial and mammalian site-specific mutagenesis systems. The ras oncogene was discovered in the Harvey and Kirsten murine sarcoma viruses (92).

Mutations in codon 61 activate the oncogene. Mutations in ras are frequently detected alteration in human tumors (92-97). The identity of the duplex was verified using MALDI-TOF mass spectrometry. Mass measurement showed two signals corresponding to mass units of 3485 and 3274, which originated from the cross-linked adduct strand 5'-d(CGGACXYGAAG)- $3^{\prime}$ and the complementary strand $5^{\prime}$-d(CTTCTTGTCCG)-3', respectively. Melting temperature of the $(S, S)$-BD-(61-2,3) duplex was $43^{\circ} \mathrm{C}$, lower than the $57^{\circ} \mathrm{C}$ melting temperature of the unmodified ras 61 duplex and the $50^{\circ} \mathrm{C}$ of the $(R, R)$-BD-(61-2,3) duplex (69). The cross-linked sample yielded excellent NMR data in the temperature range of $10^{\circ} \mathrm{C}-25^{\circ} \mathrm{C}$.

\section{DNA ${ }^{1} \mathrm{H}$ Resonance Assignments}

(a) Non-exchangeable Protons-The sequential assignment for the (S,S)-BD-(61-2,3) cross-linked duplex was accomplished using standard protocols $(98,99)$. The sequential NOEs between the aromatic and anomeric protons of the $(S, S)$-BD-(61-2,3) cross-linked oligodeoxynucleotide duplex are displayed in Figure 1. For the modified strand, weak NOE connectivities were observed between $\mathrm{X}^{6} \mathrm{H} 1^{\prime}$ to $\mathrm{Y}^{7} \mathrm{H} 8$ and $\mathrm{Y}^{7} \mathrm{H}^{\prime}$ to $\mathrm{G}^{8} \mathrm{H} 8$. In the complementary strand, the connectivity between $\mathrm{T}^{16} \mathrm{H} 1^{\prime}$ and $\mathrm{T}^{17} \mathrm{H} 6$ was interrupted. The complete assignments of the deoxyribose $\mathrm{H}^{\prime}, \mathrm{H} 2^{\prime \prime}$ and $\mathrm{H} 3^{\prime}$ protons were achieved and partial assignments were made for the deoxyribose $\mathrm{H}^{\prime}, \mathrm{H} 5^{\prime}$ and $\mathrm{H} 5^{\prime \prime}$ protons due to heavy overlap.

(b) Exchangeable Protons-A plot of the region ranging from 11 to $15 \mathrm{ppm}$ of the NOESY experiment is shown in Figure 2. The imino cross peaks located in this region were wellresolved, with the exception of $\mathrm{T}^{14}$ and $\mathrm{T}^{16}$, which were overlapped. The assignments of the thymine imino resonances were confirmed by the identification of cross peaks to adenosine $\mathrm{H} 2$ protons of each A.T pair, as shown in Figure 2B. Cross peaks arising from the $\mathrm{Y}^{7} \mathrm{H} 2$ to $\mathrm{T}^{16} \mathrm{~N} 3 \mathrm{H}$ and $\mathrm{A}^{9} \mathrm{H} 2$ to $\mathrm{T}^{14} \mathrm{~N} 3 \mathrm{H}$ NOEs confirmed that both $\mathrm{T}^{14} \mathrm{~N} 3 \mathrm{H}$ and $\mathrm{T}^{16} \mathrm{~N} 3 \mathrm{H}$ resonated at $13.8 \mathrm{ppm}$. The sequential connectivities of the imino protons were obtained from base pairs $\mathrm{G}^{2} \cdot \mathrm{C}^{21} \rightarrow \mathrm{C}^{5} \cdot \mathrm{G}^{18}$ and $\mathrm{Y}^{7} \cdot \mathrm{T}^{16} \rightarrow \mathrm{A}^{10} \cdot \mathrm{T}^{13}$, with breaks in connectivity observed between base pairs $C^{5} \cdot G^{18} \rightarrow X^{6} \cdot C^{17}$ and between $X^{6} \cdot C^{17} \rightarrow Y^{7} \cdot T^{16}$. The NOE between $T^{17} N 3 H$ and $X^{6}$ $\mathrm{H} 2$ was of reduced intensity. The NOE between $\mathrm{T}^{16} \mathrm{~N} 3 \mathrm{H}$ and $\mathrm{Y}^{7} \mathrm{H} 2$ was also weak. The imino resonances from the terminal base pairs $C^{1} \cdot G^{22}$ and $G^{11} \cdot C^{12}$ were missing, which presumably reflected the effects of strand fraying and resulting rapid exchange of this proton with solvent.

\section{Butadiene Protons}

The butadiene cross-link protons were assigned by the combined use of DQF-COSY, TOCSY and NOESY spectra. As shown in Figure 3, at a mixing time of $250 \mathrm{~ms}$, NOEs were observed between the butadiene cross-link protons. The $\mathrm{H}_{\alpha}$ proton at $2.87 \mathrm{ppm}$ showed strong NOEs to $\mathrm{H}_{\alpha^{\prime}}$ at $3.32 \mathrm{ppm}$ and $\mathrm{H}_{\beta}$ at $3.89 \mathrm{ppm}$, along with a weak NOE to $\mathrm{H}_{\gamma}$ at $3.95 \mathrm{ppm}$. The $\mathrm{H}_{\beta}$ proton showed NOEs to $\mathrm{H}_{\alpha}, \mathrm{H}_{\alpha^{\prime}}$ and $\mathrm{H}_{\gamma}$, along with a weak NOE to $\mathrm{H}_{\delta}$ at $3.01 \mathrm{ppm}, \mathrm{H}_{\delta^{\prime}}$ at $3.71 \mathrm{ppm}$. The $\mathrm{H}_{\gamma}$ proton exhibited NOEs to $\mathrm{H}_{\delta}$ and $\mathrm{H}_{\delta^{\prime}}$, along with weak NOEs to $\mathrm{H}_{\alpha}$ and $\mathrm{H}_{\alpha^{\prime}}$.

\section{Butadiene-DNA NOEs}

A total of 5 NOEs were observed between the BD protons and the DNA. Some of these are shown in Figure 4. The $\mathrm{H}_{\alpha}$ and $\mathrm{H}_{\alpha^{\prime}}$ protons exhibited cross peaks to 5' direction neighboring 
base $\mathrm{C}^{5} \mathrm{H} 5$. NOEs were also observed between butadiene protons $\mathrm{H}_{\alpha}, \mathrm{H}_{\alpha^{\prime}}, \mathrm{H}_{\beta}$ and the exchangeable proton $\mathrm{T}^{17} \mathrm{~N} 3 \mathrm{H}$. These NOEs established the orientation of the butadiene crosslink in the major groove.

\section{Torsion Angle Measurements}

Analysis of DQF-COSY data suggested that all deoxyribose pseudorotation angles remained in the $\mathrm{C} 2^{\prime}$-endo sugar ring conformation anticipated for B-family DNA. The glycosyl torsion angle conformations were evaluated by inspection of ${ }^{1} \mathrm{H}$ NOESY data. The weak NOEs between the purine $\mathrm{H} 8$ or pyrimidine $\mathrm{H} 6$ protons and the anomeric $\mathrm{H} 1$ ' protons of the attached deoxyribose sugars were consistent with glycosyl torsion angles in the normal anti conformational range. Measurements for the phosphodiester backbone torsion angles $\varepsilon$ and $\zeta$ were obtained from a heteronuclear ${ }^{1} \mathrm{H}_{-}{ }^{31} \mathrm{P}$ correlation experiment. The ${ }^{31} \mathrm{P}$ chemical shifts were observed in the expected chemical shift range for B-DNA. There were also no unusual ${ }^{3} \mathrm{~J}{ }^{1} \mathrm{H}-{ }^{31} \mathrm{P}$ couplings observed in the ${ }^{31} \mathrm{P}$ spectrum. Data obtained from ${ }^{3} \mathrm{~J}{ }^{1} \mathrm{H}_{-}{ }^{31} \mathrm{P}$ experiments indicated that the torsion angles associated with the backbone phosphodiester linkages were not significantly perturbed by the presence of the cross-link.

\section{Chemical shift effects}

The ${ }^{1} \mathrm{H}$ spectrum of the cross-linked duplex exhibited significant chemical shift differences at the modified base $\mathrm{X}^{6}$ and its complementary base $\mathrm{T}^{17}$ as compared to that of the unmodified ras61 oligodeoxynucleotide (Figure 5). An upfield chemical shift of $0.36 \mathrm{ppm}$ was observed for $\mathrm{X}^{6} \mathrm{H1}$, while a downfield shift of $0.29 \mathrm{ppm}$ was observed for $\mathrm{T}^{17} \mathrm{H} 6$. For the imino protons, the greatest downfield shift of $0.46 \mathrm{ppm}$ was observed for $\mathrm{T}^{17} \mathrm{~N} 3 \mathrm{H}$. Other smaller chemical shifts were observed for a number of protons near the adduction sites.

\section{Structural Refinement}

The structural refinement utilized a simulated annealing protocol for the molecular dynamics calculations. The Generalized Born model was utilized to approximate charge-charge interactions in the presence of a continuum solvent $(86,87)$. The molecular dynamics calculations were restrained by 413 experimental distance restraints, including the 5 NOEs between the BD protons and the DNA. These were evenly distributed over the length of the oligodeoxynucleotide. In addition to the NOE-based distance restraints, 90 deoxyribose pseudorotation restraints, 104 empirical phosphodiester backbone angle measurements and 39 hydrogen bonding restraints were included in the calculations.

Sets of randomly seeded rMD calculations were carried out from both B-form DNA and Aform DNA starting structures. These starting structures exhibited a root mean square deviation (rmsd) of $6.26 \AA$. The structures that emerged following 40 ps of rMD were subjected to potential energy minimization and evaluated as to pairwise rmsd. Irrespective of starting structure, two ensembles of structures emerged from the calculations. In the first, designated conformation $\mathrm{I}$, the butadiene $\mathrm{C}_{\beta}$-hydroxyl proton was within hydrogen bonding distance of $\mathrm{T}^{16} O^{4}$. The maximum pairwise rmsd for this ensemble of structures was $0.87 \AA$. In the second, designated conformation II, the butadiene $\beta$-hydroxyl proton was within hydrogen bonding distance of $\mathrm{T}^{17} O^{4}$. The maximum pairwise rmsd for this ensemble of structures was $0.85 \AA$ (Table 1). Stereoviews of the two different energy minimized structures that emerged from the randomly-seeded rMD calculations are shown in Figure 6.

The two sets of converged structures, conformations I and II, that emerged from the rMD calculations were assessed by complete relaxation matrix calculations, using the program CORMA (v. 4.0) (75). These calculations yielded sixth root residuals $\left(\mathrm{R}_{1}{ }^{\mathrm{x}}\right.$ values) between the NOE intensities predicted by the refined structures and the experimentally measured NOE intensities. Figure 7 shows $\mathrm{R}_{1}{ }^{\mathrm{x}}$ values as a function of nucleotide position. For both 
conformations I and II, the calculations revealed reasonable agreement between calculated intensities and experimental NOE data. This reflected the fact that the two conformations differed only in the orientation of the butadiene $\mathrm{C}_{\beta}$-hydroxyl group, and the magnitudes of most or all of the 5 butadiene-DNA NOEs did not differ between the two potential conformations. The residual values were consistent over the length of the modified oligodeoxynucleotide, ranging from 0.017 to 0.152 . It was concluded that either conformations I or II, or an equilibrium mixture of the two, could be consistent with the available NOE data, and most likely, the observed spectral data reflected the presence of an equilibrium mixture of both conformations, in rapid exchange on the NMR time scale.

\section{Structure of the (S,S)-BD-(61-2,3) Cross-linked Adduct}

The $(S, S)$-BD-(61-2,3) butadiene cross-link was oriented in the major groove, as shown in Figure 8. In the four carbon butadiene-derived cross-link the two hydroxyl groups at $\mathrm{C}_{\beta}$ and $\mathrm{C}_{\gamma}$ were in the anti conformation with respect to the $\mathrm{C}_{\beta}-\mathrm{C}_{\gamma}$ bond. This allowed the $\mathrm{C}_{\beta}-\mathrm{OH}$ group to insert between $\mathrm{T}^{16}$ and $\mathrm{T}^{17}$ in the complementary strand, while allowing the $\mathrm{C}_{\gamma}$-OH group to orient into the major groove and away from the DNA helix. It resulted in distortions of base pairs $X^{6} \cdot T^{17}$ and $Y^{7} \cdot T^{16}$ (Figure 9). Nevertheless, base pairs $X^{6} \cdot T^{17}$ and $Y^{7} \cdot T^{16}$ remained inserted into the DNA duplex, and base stacking (Figure 10) was minimally perturbed, as compared to the corresponding stacking interactions between $\mathrm{A}^{6}$ and $\mathrm{A}^{7}$ in the unmodified ras 61 oligodeoxynucleotide (100). Helicoidal analysis suggested a $10^{\circ}$ decrease of the twist angle between base pairs $X^{6} \cdot T^{17}$ and $Y^{7} \cdot T^{16}$, resulting in an unwinding of the duplex (89). An approximate $10^{\circ}$ bending of the cross-linked duplex was calculated using the program CURVES $(90,91)$, probably a consequence of placing the two hydroxyl groups at $\mathrm{C}_{\beta}$ and $\mathrm{C}_{\gamma}$ in the anti conformation with respect to the $\mathrm{C}_{\beta}-\mathrm{C}_{\gamma}$ bond, which did not allow the four carbon cross-link to exist in the extended chain conformation. The presence of the $\mathrm{C}_{\beta}-\mathrm{OH}$ group inserted between $\mathrm{T}^{16}$ and $\mathrm{T}^{17}$ in the complementary strand allowed it to swivel either towards $\mathrm{T}^{16} \mathrm{O}^{4}$ or $\mathrm{T}^{17} \mathrm{O}^{4}$. Thus, two potential conformations of the $(S, S)$-BD-(61-2,3) crosslinked adduct in the ras61 oligodeoxynucleotide differed in hydrogen bonding interactions between the $\mathrm{C}_{\beta}$ - $\mathrm{OH}$ group of the cross-link and $\mathrm{T}^{17} O^{4}$ (conformation I) or $\mathrm{T}^{16} O^{4}$ (conformation II).

\section{Discussion}

The genotoxicity of butadiene may be related to its ability to form cross-links in DNA via its diepoxide oxidation product. Animal studies revealed species differences between mice and rats with regard to $\mathrm{BD}$ genotoxicity, which mice exhibiting greater sensitivity $(7,8,101)$. This was explained by the observation that in mice the conversion of $\mathrm{BD}$ to $\mathrm{BDO}_{2}$ was more efficient than in rats, an observation which also pointed to $\mathrm{BDO}_{2}$ as the key proximate electrophile in BD-mediated genotoxicity (52). This suspicion was confirmed by studies showing that $\mathrm{BDO}_{2}$ was indeed considerably more mutagenic than the mono-epoxide EB (37)—probably due to its cross-linking ability. The primary evidence suggesting the presence of $\mathrm{DBO}_{2}$-induced DNA cross-links in vivo comes from studies in which human lymphoblastoid TK6 and splenic $\mathrm{T}$ cells were exposed to low levels of $\mathrm{BDO}_{2}(37,102,103)$. These experiments revealed transitions and transversions at both $\mathrm{G} \bullet \mathrm{C}$ and $\mathrm{A} \bullet \mathrm{T}$ sites, suggesting the presence of both $\mathrm{dG}$ and $\mathrm{dA}$ adducts arising from $\mathrm{BDO}_{2}$. They also revealed the presence of significant levels of deletion mutants, consistent with the presence of DNA cross-links $(37,102,103)$.

\section{Structural Analysis of (S,S)-BD-(61-2,3) Cross-link}

The major groove orientation of the $(S, S)$-BD-(61-2,3) cross-link was consistent with the observation of few NOEs between the butadiene cross-link and the DNA, placing the butadiene protons far from major groove non-exchangeable DNA protons. Nevertheless, the NOEs between the butadiene $\mathrm{H}_{\alpha}$ and $\mathrm{H}_{\alpha^{\prime}}$ protons and major groove $\mathrm{C}^{5} \mathrm{H} 5$ proton of the $5^{\prime}$ neighboring 
base served to locate the cross-link in the major groove. The NOEs observed between the butadiene $\mathrm{H}_{\alpha, \alpha^{\prime}}, \mathrm{H}_{\beta}$ and the exchangeable proton $\mathrm{T}^{17} \mathrm{~N} 3 \mathrm{H}$ further oriented the cross-link in the major groove. The anti conformation of the two hydroxyl groups at $\mathrm{C}_{\beta}$ and $\mathrm{C}_{\gamma}$ with respect to the $C_{\beta}-C_{\gamma}$ bond resulted in a decrease of the twist angle between base pairs $X^{6} \cdot T^{17}$ and $\mathrm{Y}^{7} \cdot \mathrm{T}^{16}$, and an approximate $10^{\circ}$ bending of the cross-linked DNA duplex. This was accompanied by disruption of Watson-Crick hydrogen bonding at base pair $\mathrm{X}^{6} \cdot \mathrm{T}^{17}$. The observation of a break in sequential NOE connectivity between $\mathrm{T}^{16} \mathrm{H}^{6}$ and $\mathrm{T}^{17} \mathrm{H} 1^{\prime}$ (Figure 1) and the 0.46 and 0.29 ppm upfield shifts of the $\mathrm{T}^{17} \mathrm{~N} 3 \mathrm{H}$ and $\mathrm{T}^{17} \mathrm{H} 6$ resonances, respectively (Figure 2), supported the conclusion that Watson-Crick base-pairing was disrupted at base pair $\mathrm{X}^{6} \cdot \mathrm{T}^{17}$. This probably also explained the reduction in the $T_{\mathrm{m}}$ of the $(S, S)$-BD-(61-2,3) crosslinked duplex as compared to that of the unmodified ras 61 duplex. The potential formation of a hydrogen bond between the $\mathrm{C}_{\beta}$-OH group of the cross-link and either $\mathrm{T}^{16} O^{4}$ or $\mathrm{T}^{17} O^{4}$, predicted by the rMD calculations, probably stabilized the conformation of the cross-link.

\section{Comparison with the $(R, R)-\mathrm{BD}-(61-2,3)$ Cross-linked Adduct}

Like the $(R, R)$-BD-(61-2,3) cross-link, the $(S, S)$-BD-(61-2,3) cross-link was oriented in the major groove of the DNA. For both cross-links, Watson-Crick base pairing was disrupted at base pair $\mathrm{X}^{6} \cdot \mathrm{T}^{17}$, whereas base pair $\mathrm{Y}^{7} \cdot \mathrm{T}^{16}$, base pairing was less perturbed. The major conformational difference between the $(R, R)$-BD-(61-2,3) and $(S, S)$-BD-(61-2,3) cross-links was in the conformation of the four carbon butadiene chain. For the $(R, R)$-BD-(61-2,3) crosslink, the butadiene linkage existed in an extended chain conformation, placing the two hydroxyl groups at $\mathrm{C}_{\beta}$ and $\mathrm{C}_{\gamma}$ in the syn conformation with respect to the $\mathrm{C}_{\beta}-\mathrm{C}_{\gamma}$ bond. This allowed the $(R, R)$-BD-(61-2,3) cross-link to be accommodated within the major groove of the DNA with minimal structural perturbation of the duplex. In contrast, the anti conformation of the two hydroxyl groups at $\mathrm{C}_{\beta}$ and $\mathrm{C}_{\gamma}$ with respect to the $\mathrm{C}_{\beta}-\mathrm{C}_{\gamma}$ bond in the $(S, S)$-BD-(61-2,3) crosslink required greater structural perturbation to the DNA duplex, resulting in a decreased twist between base pairs $\mathrm{X}^{6} \cdot \mathrm{T}^{17}$ and $\mathrm{Y}^{7} \cdot \mathrm{T}^{16}$, and an approximate $10^{\circ}$ bending of the cross-linked duplex.

\section{Structure-Activity Relationships}

The present results confirm a role for stereochemistry in modulating the conformations of the diastereomeric $(R, R)$ - and $(S, S)$-BD-(61-2,3) butadiene-derived cross-links. While the $(R, R)$ BD-(61-2,3) cross-link existed in the extended chain conformation with minimal perturbation of the DNA duplex, the $(S, S)$-BD-(61-2,3) cross-link created a greater structural perturbation at base pairs $\mathrm{X}^{6} \cdot \mathrm{T}^{17}$ and $\mathrm{Y}^{7} \cdot \mathrm{T}^{16}$. These differential structural perturbations could influence the recognition and biological processing of these cross-links. Although both $(R, R)$ - and $(S, S)$-BD-(61-2,3) cross-links were highly mutagenic in both Escherichia coli and COS-7 cells, the $(S, S)$-BD-(61-2,3) cross-link exhibited a somewhat lower overall mutagenic frequency $(20 \%)$ than that of $(R, R)$-BD-(61-2,3) cross-linked adduct (54\%) (58).

Park et al. (56) proposed a model in which the differences between the ability of different $\mathrm{BDO}_{2}$ stereoisomers to induce $\mathrm{N} 7, \mathrm{~N} 7-\mathrm{dG}$ cross-links might be caused by different orientations of functional groups in stereoisomeric N7-(2'-hydroxy-3',4'-epoxybut-1'-yl)-guanine intermediates. Thus, for $S, S$ - and $R, R$-N7-(2'-hydroxy-3', $4^{\prime}$-epoxybut-1'-yl)-guanine, the oxirane and the $2^{\prime}$-hydroxy group reside on one side of the plane formed by the carbon chain, while, in the cross-link arising from the meso $\mathrm{BDO}_{2}$, the oxirane and the $2^{\prime}-\mathrm{OH}$ are on different sides of the plane, potentially influencing the site of the second alkylation. Molecular modeling suggested that formation of a hydrogen bond between the $2^{\prime}$-hydroxy group in $S, S$ - and $R, R$ N7-(2'-hydroxy-3',4'-epoxybut-1'-yl)-guanine and N3 of the 3'-neighbor dG would position the oxirane favorably for alkylation at N7-dG in the opposite strand. In contrast, formation of a hydrogen bond between the 2'-hydroxyl and 3'-neighbor dG in meso-DEB-induced $S, R$ and $R, S$ epoxy alcohol intermediates would stabilize the conformation in which the oxirane faced 
N7-dG in the opposite strand. As a result, the regiochemistry of cross-linking would differ. Likewise, for the $S, S-N^{6}-\left(2^{\prime}, 3^{\prime}, 4^{\prime}\right.$-trihydroxybut-1'-yl)-deoxyadenosyl adduct hydrogen bond formation was observed between the -OH of the side chain and the $O^{4}$ of thymine in the opposite strand, while, for the $R, R$ adduct, hydrogen bonding was formed between the $-\mathrm{OH}$ and the thymine $O^{4}$ in the opposite DNA strand (104).

\section{Biological Significance}

Mammalian mutagenesis studies performed on $\mathrm{B} 6 \mathrm{c} 3 \mathrm{~F} 1$ lacI transgenic mice showed point mutations at both $\mathrm{dG}$ and $\mathrm{dA}$; the primary adenine-specific point mutations were $\mathrm{A} \rightarrow \mathrm{T}$ transversions (105-109). The site specific mutagenesis experiments on both stereoisomers of $N^{6}, N^{6}$-dA intrastrand cross-linked adducts yielded primarily A $\rightarrow$ G mutations (58), indicating that the $\mathrm{BDO}_{2}$-induced cross-linked adducts did not represent the source of the predominant $\mathrm{A} \rightarrow \mathrm{T}$ mutations induced by butadiene in bacterial or in mammalian cells. Nonetheless, butadiene was reported to induce $\mathrm{A} \rightarrow \mathrm{G}$ transitions in the $\mathrm{H}-$ ras locus (110), to which might be attributed to $\mathrm{BDO}_{2}$-induced cross-links. The N1-deoxyinosine adducts represent another potential source of $A \rightarrow G$ transitions. Site-specific mutagenesis studies of the N1-deoxyinosine adducts arising from BDO in the COS-7 cells revealed that they were strongly mutagenic with respect to $\mathrm{A} \rightarrow \mathrm{G}$ mutations. Consequently, the specific DNA adducts arising from exposure to $\mathrm{BD}$ and responsible for inducing $\mathrm{A} \rightarrow \mathrm{T}$ mutations remain to be determined. Mutagenesis studies of the $(S, S)$-BD-(61-2,3) cross-linked adduct suggested that $\mathrm{A} \rightarrow \mathrm{G}$ transitions at the $3^{\prime}$ adenine were the primary point mutations in both $E$. coli and COS-7 cells, the same results were observed for the $(R, R)$-BD-(61-2,3) cross-linked adduct. This observation suggested that both stereoisomeric cross-linked adducts facilitate mis-incorporation of dCTP opposite crosslinked nucleotide $\mathrm{Y}^{7}$. Examination of the structure of a mismatched dC opposite the $N^{6}, N^{6}$ dA cross-linked adduct will be of interest. The predominant adducts formed upon exposure of DNA to butadiene epoxides are N7-dG adducts (111). The N7-N7 guanine interstrand crosslinked adduct has been determined to be the major DNA-DNA cross-link induced by $\mathrm{BDO}_{2}$ (17). It will also be of considerable interest to examine the structures of N7-guanine adducts.

\section{Summary}

The $(S, S)$-BD-(61-2,3) cross-linked adduct at $N^{6}$ in the ras61 coding sequence oriented in the major groove, resulting in the opening of base pair $\mathrm{X}^{6} \cdot \mathrm{T}^{17}$. Two potential conformations obtained from NMR data refinement exhibited similar structures with different hydrogen bonding interactions between the $\mathrm{C}_{\beta}$ - $\mathrm{OH}$ group of the cross-link and $\mathrm{T}^{16} O^{4}$ or $\mathrm{T}^{17} O^{4}$, respectively.

\section{Supplementary Material}

Refer to Web version on PubMed Central for supplementary material.

\section{Acknowledgements}

We acknowledge the contributions of Mr. Markus Voehler and Dr. Jaison Jacob, who assisted with NMR spectroscopy. Dr. Jarrod Smith and Dr. Feng Wang assisted with structural refinement.

\section{References}

1. Himmelstein MW, Acquavella JF, Recio L, Medinsky MA, Bond JA. Toxicology and epidemiology of 1,3-butadiene. Crit. Rev. Toxicol 1997;27:1-108. [PubMed: 9115622]

2. Jackson MA, Stack HF, Rice JM, Waters MD. A review of the genetic and related effects of 1,3butadiene in rodents and humans. Mutat. Res 2000;463:181-213. [PubMed: 11018742] 
3. Pelz N, Dempster NM, Shore PR. Analysis of low molecular weight hydrocarbons including 1,3butadiene in engine exhaust gases using an aluminum oxide porous-layer open-tubular fused-silica column. J. Chromatogr. Sci 1990;28:230-235. [PubMed: 1704381]

4. Brunnemann KD, Kagan MR, Cox JE, Hoffmann D. Analysis of 1,3-butadiene and other selected gasphase components in cigarette mainstream and sidestream smoke by gas chromatography-mass selective detection. Carcinogenesis 1990;11:1863-1868. [PubMed: 2208599]

5. Huff JE, Melnick RL, Solleveld HA, Haseman JK, Powers M, Miller RA. Multiple organ carcinogenicity of 1,3-butadiene in B6c3F1 mice after 60 weeks of inhalation exposure. Science 1985;227:548-549. [PubMed: 3966163]

6. Melnick RL, Huff J, Chou BJ, Miller RA. Carcinogenicity of 1,3-butadiene in C57BL/6 × C3H F1 mice at low exposure concentrations. Cancer Res 1990;50:6592-6599. [PubMed: 2208121]

7. Melnick RL, Huff JE, Roycroft JH, Chou BJ, Miller RA. Inhalation toxicology and carcinogenicity of 1,3-butadiene in B6c3F1 mice following 65 weeks of exposure. Environ. Health Perspect 1990;86:2736. [PubMed: 2401263]

8. Owen PE, Glaister JR. Inhalation toxicity and carcinogenicity of 1,3-butadiene in sprague- dawley rats. Environ. Health Perspect 1990;86:19-25. [PubMed: 2401255]

9. United States Environmental Protection Agency. 1,3-Butadiene. Carcinogenicity assessment for lifetime exposure: Weight-of-evidence characterization. 2002. Available at http://www.epa.gov/iris/subst/0139.htm

10. International Agency for Research on Cancer. Re-evaluation of some organic chemicals, hydrazine and hydrogen peroxide, IRC Monographs on the Evaluation of Carcinogenic Risks to Humans. IARC Sci. Publ 1999;71:109-125.

11. Bird MG, Rice JM, Bond JA. Evaluation of 1,3-butadiene, isoprene and chloroprene health risks. Chem. Biol. Interact 2001;135-136:1-7.

12. Rice JM, Boffetta P. 1,3-Butadiene, isoprene and chloroprene: Reviews by the IARC monographs programme, outstanding issues, and research priorities in epidemiology. Chem. Biol. Interact 2001;135-136:11-26.

13. Ward JB Jr, Ammenheuser MM, Bechtold WE, Whorton EB Jr, Legator MS. Hprt mutant lymphocyte frequencies in workers at a 1,3-butadiene production plant. Environ. Health Perspect 1994;102:7985. [PubMed: 7698091]

14. Ward JB Jr, Ammenheuser MM, Whorton EB Jr, Bechtold WE, Kelsey KT, Legator MS. Biological monitoring for mutagenic effects of occupational exposure to butadiene. Toxicology 1996;113:8490. [PubMed: 8901886]

15. Sram RJ, Rossner P, Peltonen K, Podrazilova K, Mrackova G, Demopoulos NA, Stephanou G, Vlachodimitropoulos D, Darroudi F, Tates AD. Chromosomal aberrations, sister-chromatid exchanges, cells with high frequency of SCE, micronuclei and comet assay parameters in 1, 3butadiene-exposed workers. Mutat. Res 1998;419:145-154. [PubMed: 9804932]

16. Delzell E, Sathiakumar N, Hovinga M, Macaluso M, Julian J, Larson R, Cole P, Muir DC. A followup study of synthetic rubber workers. Toxicology 1996;113:182-189. [PubMed: 8901897]

17. Meinhardt TJ, Lemen RA, Crandall MS, Young RJ. Environmental epidemiologic investigation of the styrene-butadiene rubber industry. mortality patterns with discussion of the hematopoietic and lymphatic malignancies. Scand. J. Work. Environ. Health 1982;8:250-259. [PubMed: 7170621]

18. Matanoski G, Francis M, Correa-Villasenor A, Elliott E, Santos-Burgoa C, Schwartz L. Cancer epidemiology among styrene-butadiene rubber workers. IARC Sci. Publ 1993;127:363-374. [PubMed: 8070882]

19. Santos-Burgoa C, Matanoski GM, Zeger S, Schwartz L. Lymphohematopoietic cancer in styrenebutadiene polymerization workers [see comments]. Am. J. Epidemiol 1992;136:843-854. [PubMed: 1442750]

20. Macaluso M, Larson R, Delzell E, Sathiakumar N, Hovinga M, Julian J, Muir D, Cole P. Leukemia and cumulative exposure to butadiene, styrene and benzene among workers in the synthetic rubber industry. Toxicology 1996;113:190-202. [PubMed: 8901898]

21. Matanoski GM, Schwarts L. Mortality of workers in styrene-butadiene polymer production. J. Occup. Med 1987;29:675-680. [PubMed: 3655951] 
22. Santos-Burgoa C, Eden-Wynter RA, Riojas-Rodriguez H, Matanoski GM. Living in a chemical world. Health impact of 1,3-butadiene carcinogenesis. Ann. N. Y. Acad. Sci 1997;837:176-188. [PubMed: 9472340]

23. Matanoski G, Elliott E, Tao X, Francis M, Correa-Villasenor A, Santos-Burgoa C. Lymphohematopoietic cancers and butadiene and styrene exposure in synthetic rubber manufacture. Ann. N. Y. Acad. Sci 1997;837:157-169. [PubMed: 9472338]

24. Albertini R, Clewell H, Himmelstein MW, Morinello E, Olin S, Preston J, Scarano L, Smith MT, Swenberg J, Tice R, Travis C. The use of non-tumor data in cancer risk assessment: Reflections on butadiene, vinyl chloride, and benzene. Regul. Toxicol. Pharmacol 2003;37:105-132. [PubMed: 12662914]

25. Csanady GA, Guengerich FP, Bond JA. Comparison of the biotransformation of 1,3-butadiene and its metabolite, butadiene monoepoxide, by hepatic and pulmonary tissues from humans, rats and mice [published erratum appears in Carcinogenesis 1993 Apr;14(4):784]. Carcinogenesis 1992;13:11431153. [PubMed: 1638680]

26. Duescher RJ, Elfarra AA. Human liver microsomes are efficient catalysts of 1,3-butadiene oxidation: Evidence for major roles by cytochromes P450 2A6 and 2E1. Arch. Biochem. Biophys 1994;311:342-349. [PubMed: 8203896]

27. Malvoisin E, Evrard E, Roberfroid M, Mercier M. Determination of Kovats retention indices with a capillary column and electron-capture detection: Application to the assay of the enzymatic conversion of 3,4-epoxy-1-butene into diepoxybutane. J. Chromatogr 1979;186:81-87. [PubMed: 546942]

28. Seaton MJ, Follansbee MH, Bond JA. Oxidation of 1,2-epoxy-3-butene to 1,2:3,4-diepoxybutane by cDNA-expressed human cytochromes P450 2E1 and 3A4 and human, mouse and rat liver microsomes. Carcinogenesis 1995;16:2287-2293. [PubMed: 7586124]

29. Malvoisin E, Roberfroid M. Hepatic microsomal metabolism of 1,3-butadiene. Xenobiotica 1982;12:137-144. [PubMed: 7090423]

30. Himmelstein MW, Turner MJ, Asgharian B, Bond JA. Comparison of blood concentrations of 1,3butadiene and butadiene epoxides in mice and rats exposed to 1,3-butadiene by inhalation. Carcinogenesis 1994;15:1479-1486. [PubMed: 8055623]

31. Himmelstein MW, Asgharian B, Bond JA. High concentrations of butadiene epoxides in livers and lungs of mice compared to rats exposed to 1,3-butadiene. Toxicol. Appl. Pharmacol 1995;132:281288. [PubMed: 7785055]

32. Cheng X, Ruth JA. A simplified methodology for quantitation of butadiene metabolites. Application to the study of 1,3-butadiene metabolism by rat liver microsomes. Drug Metab. Dispos 1993;21:121124. [PubMed: 8095204]

33. Nauhaus SK, Fennell TR, Asgharian B, Bond JA, Sumner SC. Characterization of urinary metabolites from Sprague-Dawley rats and $\mathrm{B} 6 \mathrm{c} 3 \mathrm{~F} 1$ mice exposed to $\left[1,2,3,4-{ }^{13} \mathrm{C}\right]$ butadiene. Chem. Res. Toxicol 1996;9:764-773. [PubMed: 8831821]

34. Kemper RA, Elfarra AA, Myers SR. Metabolism of 3-butene-1,2-diol in B6c3F1 mice. Evidence for involvement of alcohol dehydrogenase and cytochrome P450. Drug Metab. Dispos 1998;26:914920. [PubMed: 9733671]

35. Boogaard PJ, Bond JA. The role of hydrolysis in the detoxification of 1,2:3,4-diepoxybutane by human, rat, and mouse liver and lung in vitro. Toxicol. Appl. Pharmacol 1996;141:617-627. [PubMed: 8975787]

36. Powley MW, Jayaraj K, Gold A, Ball LM, Swenberg JA. 1, $N^{2}$-propanodeoxyguanosine adducts of the 1,3-butadiene metabolite, hydroxymethylvinyl ketone. Chem. Res. Toxicol 2003;16:1448-1454. [PubMed: 14615971]

37. Cochrane JE, Skopek TR. Mutagenicity of butadiene and its epoxide metabolites: I. Mutagenic potential of 1,2-epoxybutene, 1,2,3,4-diepoxybutane and 3,4-epoxy-1,2-butanediol in cultured human lymphoblasts. Carcinogenesis 1994;15:713-717. [PubMed: 8149485]

38. Verly WG, Brakier L, Feit PW. Inactivation of the T7 coliphage by the diepoxybutane stereoisomers. Biochim. Biophys. Acta 1971;228:400-406. [PubMed: 4925823]

39. Matagne R. Induction of chromosomal aberrations and mutations with isomeric forms of $L$ threitol-1,4-bismethanesulfonate in plant materials. Mutat. Res 1969;7:241-247. [PubMed: 5796521] 
40. Schmidmaier R, Oellerich M, Baumgart J, Emmerich B, Meinhardt G. Treosulfan-induced apoptosis in acute myeloid leukemia cells is accompanied by translocation of protein kinase $\mathrm{C}$ delta and enhanced by bryostatin-1. Exp. Hematol 2004;32:76-86. [PubMed: 14725904]

41. Hartley JA, O'Hare CC, Baumgart J. DNA alkylation and interstrand cross-linking by treosulfan. Br. J. Cancer 1999;79:264-266. [PubMed: 9888467]

42. Runowicz CD, Fields AL, Goldberg GL. Promising new therapies in the treatment of advanced ovarian cancer. Cancer 1995;76:2028-2033. [PubMed: 8634995]

43. Brookes P, Lawley PD. The reaction of mono and di-functional alkylating agents with nucleic acids. Biochem. J 1961;80:496-503. [PubMed: 16748923]

44. Lawley PD, Brookes P. Interstrand cross-linking of DNA by difunctional alkylating agents. J. Mol. Biol 1967;25:143-160. [PubMed: 5340530]

45. Millard JT, White MM. Diepoxybutane cross-links DNA at 5'-GNC sequences. Biochemistry 1993;32:2120-2124. [PubMed: 8448170]

46. Park S, Tretyakova N. Structural characterization of the major DNA-DNA cross-link of 1,2,3,4diepoxybutane. Chem. Res. Toxicol 2004;17:129-136. [PubMed: 14966999]

47. Valadez JG, Liu L, Loktionova NA, Pegg AE, Guengerich FP. Activation of bis-electrophiles to mutagenic conjugates by human $O^{6}$-alkylguanine-DNA alkyltransferase. Chem. Res. Toxicol 2004;17:972-982. [PubMed: 15257623]

48. Loeber R, Rajesh M, Fang Q, Pegg AE, Tretyakova N. Cross-linking of the human DNA repair protein $O^{6}$-alkylguanine DNA alkyltransferase to DNA in the presence of 1,2,3,4-diepoxybutane. Chem. Res. Toxicol 2006;19:645-654. [PubMed: 16696566]

49. Vangala RR, Laib RJ, Bolt HM. Evaluation of DNA damage by alkaline elution technique after inhalation exposure of rats and mice to 1,3-butadiene. Arch. Toxicol 1993;67:34-38. [PubMed: 8452477]

50. Ristau C, Deutschmann S, Laib RJ, Ottenwalder H. Detection of diepoxybutane-induced DNA-DNA crosslinks by cesium trifluoracetate (CsTFA) density-gradient centrifugation. Arch. Toxicol 1990;64:343-344. [PubMed: 2386432]

51. Thornton-Manning JR, Dahl AR, Bechtold WE, Griffith WCJ, Henderson RF. Comparison of the disposition of butadiene epoxides in Sprague-Dawley rats and B6c3F1 mice following a single and repeated exposures to 1,3-butadiene via inhalation. Toxicology 1997;123:125-134. [PubMed: 9347927]

52. Thornton-Manning JR, Dahl AR, Bechtold WE, Griffith WC Jr, Henderson RF. Disposition of butadiene monoepoxide and butadiene diepoxide in various tissues of rats and mice following a lowlevel inhalation exposure to 1,3-butadiene. Carcinogenesis 1995;16:1723-1731. [PubMed: 7634396]

53. Wickliffe JK, Ammenheuser MM, Salazar JJ, Abdel-Rahman SZ, Hastings-Smith DA, Postlethwait EM, Lloyd RS, Ward JB Jr. A model of sensitivity: 1,3-Butadiene increases mutant frequencies and genomic damage in mice lacking a functional microsomal epoxide hydrolase gene. Environ. Mol. Mutagen 2003;42:106-110. [PubMed: 12929123]

54. Abdel-Rahman SZ, Ammenheuser MM, Ward JB Jr. Human sensitivity to 1,3-butadiene: Role of microsomal epoxide hydrolase polymorphisms. Carcinogenesis 2001;22:415-423. [PubMed: 11238181]

55. Abdel-Rahman SZ, El-Zein RA, Ammenheuser MM, Yang Z, Stock TH, Morandi M, Ward JB Jr. Variability in human sensitivity to 1,3-butadiene: Influence of the allelic variants of the microsomal epoxide hydrolase gene. Environ. Mol. Mutagen 2003;41:140-146. [PubMed: 12605384]

56. Park S, Anderson C, Loeber R, Seetharaman M, Jones R, Tretyakova N. Interstrand and intrastrand DNA-DNA cross-linking by 1,2,3,4-diepoxybutane: Role of stereochemistry. J. Am. Chem. Soc 2005;127:14355-14365. [PubMed: 16218630]

57. Millard JT, Hanly TC, Murphy K, Tretyakova N. The 5'-GNC site for DNA interstrand cross-linking is conserved for diepoxybutane stereoisomers. Chem. Res. Toxicol 2006;19:16-19. [PubMed: 16411651]

58. Kanuri M, Nechev LV, Tamura PJ, Harris CM, Harris TM, Lloyd RS. Mutagenic spectrum of butadiene-derived N1-deoxyinosine adducts and $N^{6}, N^{6}$-deoxyadenosine intrastrand cross-links in mammalian cells. Chem. Res. Toxicol 2002;15:1572-1580. [PubMed: 12482239] 
59. Park S, Hodge J, Anderson C, Tretyakova N. Guanine-adenine DNA cross-linking by 1,2,3,4diepoxybutane: Potential basis for biological activity. Chem. Res. Toxicol 2004;17:1638-1651. [PubMed: 15606140]

60. Qian C, Dipple A. Different mechanisms of aralkylation of adenosine at the 1- and $N^{6}$ - positions. Chem. Res. Toxicol 1995;8:389-395. [PubMed: 7578925]

61. Kim HY, Finneman JI, Harris CM, Harris TM. Studies of the mechanisms of adduction of 2'deoxyadenosine with styrene oxide and polycyclic aromatic hydrocarbon dihydrodiol epoxides. Chem. Res. Toxicol 2000;13:625-637. [PubMed: 10898595]

62. Zhao C, Vodicka P, Sram RJ, Hemminki K. Human DNA adducts of 1,3-butadiene, an important environmental carcinogen. Carcinogenesis 2000;21:107-111. [PubMed: 10607741]

63. Leuratti C, Jones NJ, Marafante E, Kostiainen R, Peltonen K, Waters R. DNA damage induced by the environmental carcinogen butadiene: Identification of a diepoxybutane-adenine adduct and its detection by ${ }^{32} \mathrm{P}$-postlabelling. Carcinogenesis 1994;15:1903-1910. [PubMed: 7923584]

64. Carmical JR, Nechev LV, Harris CM, Harris TM, Lloyd RS. Mutagenic potential of adenine $N^{6}$ adducts of monoepoxide and diolepoxide derivatives of butadiene. Environ. Mol. Mutagen 2000;35:48-56. [PubMed: 10692227]

65. Carmical JR, Zhang M, Nechev L, Harris CM, Harris TM, Lloyd RS. Mutagenic potential of guanine $N^{2}$ adducts of butadiene mono- and diolepoxide [published erratum appears in Chem Res Toxicol 2000 May;13(5):430]. Chem. Res. Toxicol 2000;13:18-25. [PubMed: 10649962]

66. Latham GJ, Zhou L, Harris CM, Harris TM, Lloyd RS. The replication fate of $R$ - and $S$-styrene oxide adducts on adenine $N^{6}$ is dependent on both the chirality of the lesion and the local sequence context. J. Biol. Chem 1993;268:23427-23434. [PubMed: 8226868]

67. Kanuri M, Harris CM, Harris TML RS. Efficient non-mutagenic replication bypass of DNAs containing $\beta$-styrene oxide $N^{6}$-adenine adducts. Env. Mol. Mutagen 2001;38:357-360. [PubMed: 11774368]

68. Carmical JR, Kowalczyk A, Zou Y, Van Houten B, Nechev LV, Harris CM, Harris TM, Lloyd RS. Butadiene-induced intrastrand DNA cross-links: A possible role in deletion mutagenesis. J. Biol. Chem 2000;275:19482-19489. [PubMed: 10766753]

69. Merritt WK, Nechev LV, Scholdberg TA, Dean SM, Kiehna SE, Chang JC, Harris TM, Harris CM, Lloyd RS, Stone MP. Structure of the 1,4-bis(2'-deoxyadenosin- $N^{6}$-yl)-2R,3R-butanediol cross-link arising from alkylation of the human $N$-ras codon 61 by butadiene diepoxide. Biochemistry 2005;44:10081-10092. [PubMed: 16042385]

70. Nechev LV, Zhang M, Tsarouhtsis D, Tamura PJ, Wilkinson AS, Harris CM, Harris TM. Synthesis and characterization of nucleosides and oligonucleotides bearing adducts of butadiene epoxides on adenine $N^{6}$ and guanine $N^{2}$. Chem. Res. Toxicol 2001;14:379-388. [PubMed: 11304126]

71. Borer, PN. Handbook of Biochemistry and Molecular Biology. Cleveland, OH: CRC Press; 1975.

72. Piotto M, Saudek V, Sklenar V. Gradient-tailored excitation for single-quantum NMR spectroscopy of aqueous solutions. J. Biomol. NMR 1992;2:661-665. [PubMed: 1490109]

73. James TL. Relaxation matrix analysis of two-dimensional nuclear Overhauser effect spectra. Curr. Opin. Struct. Biol 1991;1:1042-1053.

74. Keepers JW, James TL. A theoretical study of distance determination from NMR. Two-dimensional nuclear Overhauser effect spectra. J. Magn. Reson 1984;57:404-426.

75. Keepers J, Kollman PA, James TL. Molecular mechanical studies of base-pair opening in d (CGCGC):d(GCGCG), $\mathrm{dG}_{5}: \mathrm{dC}_{5}, \mathrm{~d}(\mathrm{TATAT}): \mathrm{d}\left(\right.$ ATATA), and $\mathrm{dA}_{5}: \mathrm{dT}_{5}$ in the $\mathrm{B}$ and $\mathrm{Z}$ forms of DNA. Biopolymers 1984;23:2499-2511. [PubMed: 6518264]

76. Borgias BA, James TL. Two-dimensional nuclear Overhauser effect: complete relaxation matrix analysis. Meth. Enzymol 1989;176:169-183. [PubMed: 2811685]

77. Borgias BA, James TL. MARDIGRAS--a procedure for matrix analysis of relaxation for discerning geometry of an aqueous structure. J. Magn. Reson 1990;87:475-487.

78. Liu H, Spielmann HP, Ulyanov NB, Wemmer DE, James TL. Interproton distance bounds from 2D NOE intensities: Effect of experimental noise and peak integration errors. J. Biomol. NMR 1995;6:390-402. [PubMed: 8563467]

79. Wang H, Zuiderweg ERP, Glick GD. Solution structure of a disulfide cross-linked DNA hairpin. J. Am. Chem. Soc 1995;117:2981-2991. 
80. Geen H, Freeman R. Band-selective radiofrequency pulses. J. Magn. Reson 1991;93:93-141.

81. Lankhorst PP, Haasnoot AG, Erkelens C, Altona C. Carbon-13 NMR in conformational analysis of nucleic acid fragments. 3. The magnitude of torsional angle in $\mathrm{d}(\mathrm{TpA})$ from CCOP and HCOP NMR coupling constants. Nucleic Acids Res 1984;12:5419-5428. [PubMed: 6087285]

82. Arnott S, Hukins DWL. Optimised parameters for A-DNA and B-DNA. Biochem. Biophys. Res. Comm 1972;47:1504-1509. [PubMed: 5040245]

83. Case, DA.; Pearlman, DA.; Caldwell, JW.; Cheatham, TE., III; Wang, J.; Ross, WS.; Simmerling, CL.; Darden, TA.; Merz, KM.; Stanton, RV.; Cheng, AL.; Vincent, JJ.; Crowley, M.; Tsui, V.; Gohlke, H.; Radmer, RJ.; Duan, Y.; Pitera, J.; Massova, I.; Seibel, GL.; Singh, UC.; Weiner, PK.; Kollman, PA. AMBER 7.0. San Francisco, CA: University of California; 2002.

84. Clore GM, Brunger AT, Karplus M, Gronenborn AM. Application of molecular dynamics with interproton distance restraints to three-dimensional protein structure determination. J. Mol. Biol 1986;191:523-551. [PubMed: 3029386]

85. Ryckaert J-P, Ciccotti G, Berendsen HJC. Numerical integration of the cartesian equations of motion of a system with constraints: Molecular dynamics of n-alkanes. J. Comp. Phys 1977;23:327-341.

86. Bashford D, Case DA. Generalized Born models of macromolecular solvation effects. Annu. Rev. Phys. Chem 2000;51:129-152. [PubMed: 11031278]

87. Tsui V, Case DA. Theory and applications of the generalized Born solvation model in macromolecular simulations. Biopolymers 2000;56:275-291. [PubMed: 11754341]

88. Cornell WD, Cieplak P, Bayly CI, Gould IR, Merz KM, Ferguson DM, Spellmeyer DC, Fox T, Caldwell JW, Kollman PA. A second generation force field for the simulation of proteins, nucleic acids, and organic molecules. J. Am. Chem. Soc 1995;117:5179.

89. Lu XJ, Olson WK. 3DNA: A software package for the analysis, rebuilding and visualization of threedimensional nucleic acid structures. Nucleic Acids Res 2003;31:5108-5121. [PubMed: 12930962]

90. Lavery R, Sklenar H. The definition of generalized helicoidal parameters and of axis curvature for irregular nucleic acids. J. Biomol. Struct. Dyn 1988;6:63-91. [PubMed: 2482765]

91. Stofer E, Lavery R. Measuring the geometry of DNA grooves. Biopolymers 1994;34:337-346. [PubMed: 8161709]

92. Malumbres M, Barbacid M. RAS oncogenes: The first 30 years. Nat. Rev. Cancer 2003;3:459-465. [PubMed: 12778136]

93. Bos JL, Fearon ER, Hamilton SR, Verlaan-de Vries M, van Boom JH, van der Eb AJ, Vogelstein B. Prevalence of ras gene mutations in human colorectal cancers. Nature 1987;327:293-297. [PubMed: 3587348]

94. Forrester K, Almoguera C, Han K, Grizzle WE, Perucho M. Detection of high incidence of K-ras oncogenes during human colon tumorigenesis. Nature 1987;327:298-303. [PubMed: 2438556]

95. Rodenhuis S, van de Wetering ML, Mooi WJ, Evers SG, van Zandwijk N, Bos JL. Mutational activation of the K-ras oncogene. A possible pathogenetic factor in adenocarcinoma of the lung. N. Engl. J. Med 1987;317:929-935. [PubMed: 3041218]

96. Almoguera C, Shibata D, Forrester K, Martin J, Arnheim N, Perucho M. Most human carcinomas of the exocrine pancreas contain mutant c-K-ras genes. Cell 1988;53:549-554. [PubMed: 2453289]

97. Bos JL. ras oncogenes in human cancer: A review. Cancer Res 1989;49:4682-4689. [PubMed: 2547513]

98. Patel DJ, Shapiro L, Hare D. DNA and RNA: NMR studies of conformations and dynamics in solution. Q. Rev. Biophys 1987;20:35-112. [PubMed: 2448843]

99. Reid BR. Sequence-specific assignments and their use in NMR studies of DNA structure. Q. Rev. Biophys 1987;20:2-28.

100. Feng B, Stone MP. Solution structure of an oligodeoxynucleotide containing the human N-ras codon 61 sequence refined from ${ }^{1} \mathrm{H}$ NMR using molecular dynamics restrained by nuclear overhauser effects. Chem. Res. Toxicol 1995;8:821-832. [PubMed: 7492731]

101. Jelitto B, Vangala RR, Laib RJ. Species differences in DNA damage by butadiene: Role of diepoxybutane. Arch. Toxicol. Suppl 1989;13:246-249. [PubMed: 2774939] 
102. Cochrane JE, Skopek TR. Mutagenicity of 1,3-butadiene and its epoxide metabolites in human TK6 cells and in splenic T cells isolated from exposed B6c3F1 mice. IARC Sci. Publ 1993;127:195204. [PubMed: 8070866]

103. Cochrane JE, Skopek TR. Mutagenicity of butadiene and its epoxide metabolites: II. Mutational spectra of butadiene, 1,2-epoxybutene and diepoxybutane at the hprt locus in splenic T cells from exposed B6C3F1 mice. Carcinogenesis 15 1994;15:719-723.

104. Merritt WK, Scholdberg TA, Nechev LV, Harris TM, Harris CM, Lloyd RS, Stone MP. Stereospecific structural perturbations arising from adenine $N^{6}$ butadiene triol adducts in duplex DNA. Chem. Res. Toxicol 2004;17:1007-1019. [PubMed: 15310233]

105. Recio L, Saranko CJ, Steen AM. 1,3-butadiene: Cancer, mutations, and adducts. Part II: Roles of two metabolites of 1,3-butadiene in mediating its in vivo genotoxicity. Res. Rep. Health Eff. Inst 2000:49-87. [PubMed: 10925839]discussion 141-149

106. Recio L, Steen AM, Pluta LJ, Meyer KG, Saranko CJ. Mutational spectrum of 1,3-butadiene and metabolites 1,2-epoxybutene and 1,2,3,4-diepoxybutane to assess mutagenic mechanisms. Chem. Biol. Interact 2001;135-136:325-341.

107. Sisk SC, Pluta LJ, Bond JA, Recio L. Molecular analysis of lacI mutants from bone marrow of B6c3F1 transgenic mice following inhalation exposure to 1,3-butadiene. Carcinogenesi 1994;15:471-477.

108. Recio L, Meyer KG. Increased frequency of mutations at A:T base pairs in the bone marrow of B6c3F1 laci transgenic mice exposed to 1,3-butadiene. Environ. Mol. Mutagen 1995;26:1-8. [PubMed: 7641703]

109. Steen AM, Meyer KG, Recio L. Analysis of hprt mutations occurring in human TK6 lymphoblastoid cells following exposure to 1,2,3,4-diepoxybutane. Mutagenesis 1997;12:61-67. [PubMed: 9106245]

110. Goodrow TL, Nichols WW, Storer RD, Anderson MW, Maronpot RR. Activation of H-ras is prevalent in 1,3-butadiene-induced and spontaneously occurring murine Harderian gland tumors. Carcinogenesis 1994;15:2665-2667. [PubMed: 7955123]

111. Tretyakova NY, Chiang SY, Walker VE, Swenberg JA. Quantitative analysis of 1,3-butadieneinduced DNA adducts in vivo and in vitro using liquid chromatography electrospray ionization tandem mass spectrometry. J. Mass Spectrometry 1998;33:363-376. 


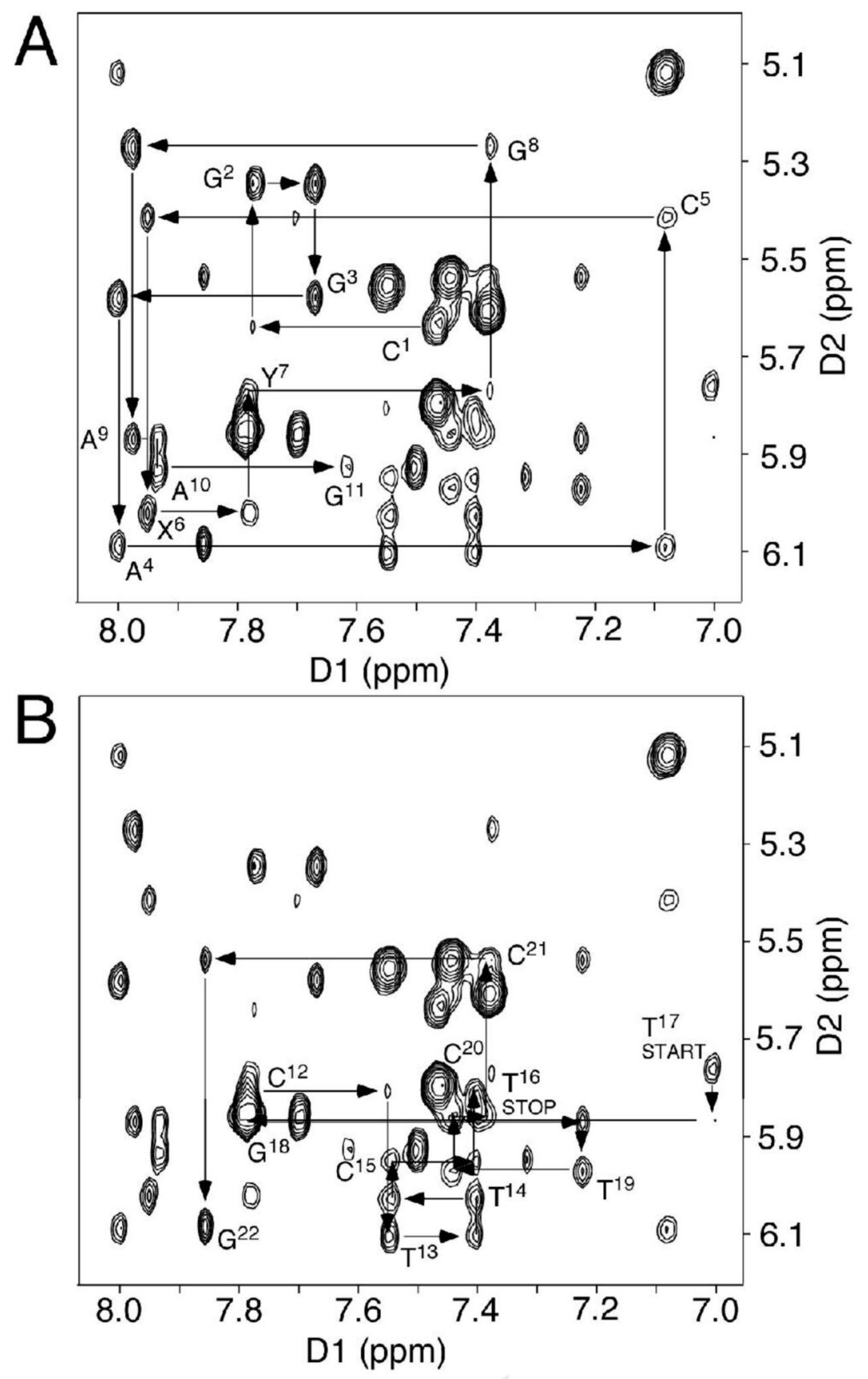

Figure 1.

Expanded plots from a NOESY spectrum showing sequential NOE connnectivities from aromatic to anomeric protons. A. Nucleotides $\mathrm{C}^{1} \rightarrow \mathrm{G}^{11}$ of the modified strand of the (S,S)-BD$(61-2,3)$ cross-linked adduct. B. Nucleotides $\mathrm{C}^{12} \rightarrow \mathrm{G}^{22}$ of the complementary strand of the $(S, S)$-BD-(61-2,3) cross-linked adduct. The experiment was carried out at a mixing time of 250 $\mathrm{ms}$ and $800 \mathrm{MHz}$. 
A

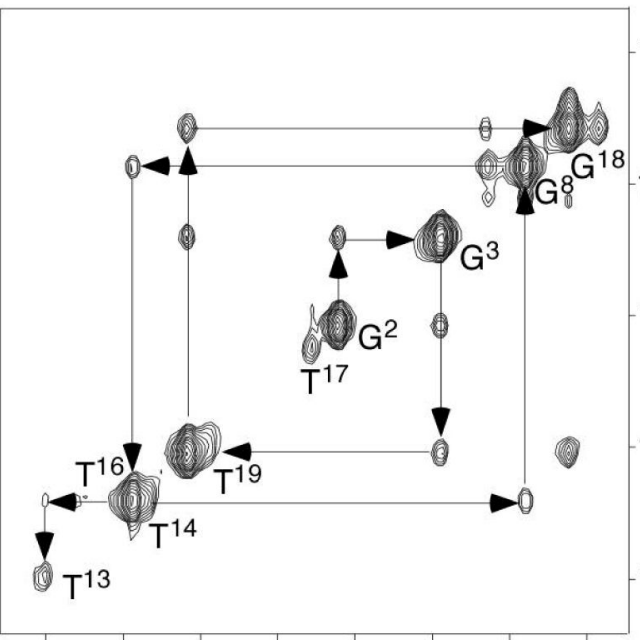

14.113 .813 .513 .212 .912 .612 .312 .0 D1 (ppm)
11.7

12.3

13.5

14.1
.7

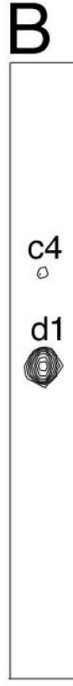

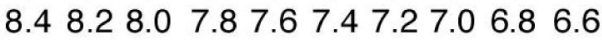
D1 (ppm)

Figure 2.

A. NOE connectivity for the imino protons for the base pairs from $G^{2} \cdot C^{21}$ to $A^{10} \cdot T^{13}$. Note the breaks in connectivity between the imino resonances for base pairs and between base pairs $\mathrm{C}^{5} \cdot \mathrm{G}^{18}$ and $\mathrm{X}^{6} \cdot \mathrm{T}^{17}$ and between $\mathrm{X}^{6} \cdot \mathrm{T}^{17}$ and $\mathrm{Y}^{7} \cdot \mathrm{T}^{16}$. The experiment was carried out at a mixing time of $250 \mathrm{~ms}$ and $800 \mathrm{MHz}$. B. NOE cross-peaks between exchangeable protons and nonexchangeable protons: a1, $\mathrm{G}^{18} \mathrm{~N} 1 \mathrm{H} \rightarrow \mathrm{G}^{18} N^{2} \mathrm{H} 1$; a2, $\mathrm{G}^{18} \mathrm{~N} 1 \mathrm{H} \rightarrow \mathrm{G}^{18} N^{2} \mathrm{H} 2$; a3, $\mathrm{G}^{18}$ $\mathrm{N} 1 \mathrm{H} \rightarrow \mathrm{A}^{4} \mathrm{H} 2 ; \mathrm{a} 4, \mathrm{G}^{18} \mathrm{~N} 1 \mathrm{H} \rightarrow \mathrm{X}^{6} \mathrm{H} 2 ; \mathrm{b} 1, \mathrm{G}^{8} \mathrm{~N} 1 \mathrm{H} \rightarrow \mathrm{G}^{8} N^{2} \mathrm{H} 1 ; \mathrm{b} 2, \mathrm{G}^{8} \mathrm{~N} 1 \mathrm{H} \rightarrow \mathrm{G}^{8} N^{2} \mathrm{H} 2 ; \mathrm{b} 3$, $\mathrm{G}^{8} \mathrm{~N} 1 \mathrm{H} \rightarrow \mathrm{A}^{9} \mathrm{H} 2 ; \mathrm{b} 4, \mathrm{G}^{8} \mathrm{~N} 1 \mathrm{H} \rightarrow \mathrm{Y}^{7} \mathrm{H} 2 ; \mathrm{c} 1, \mathrm{G}^{3} \mathrm{~N} 1 \mathrm{H} \rightarrow \mathrm{G}^{3} N^{2} \mathrm{H} 1 ; \mathrm{c} 2, \mathrm{G}^{3} \mathrm{~N} 1 \mathrm{H} \rightarrow \mathrm{G}^{3} N^{2} \mathrm{H} 2 ; \mathrm{c} 3$, $\mathrm{G}^{3} \mathrm{~N} 1 \mathrm{H} \rightarrow \mathrm{A}^{4} \mathrm{H} 2 ; \mathrm{c} 4, \mathrm{G}^{3} \mathrm{~N} 1 \mathrm{H} \rightarrow \mathrm{G}^{2} N^{2} \mathrm{H} 1 ; \mathrm{d} 1, \mathrm{G}^{2} \mathrm{~N} 1 \mathrm{H} \rightarrow \mathrm{G}^{2} N^{2} \mathrm{H} 1 ; \mathrm{d} 2, \mathrm{G}^{2} \mathrm{~N} 1 \mathrm{H} \rightarrow \mathrm{G}^{2} N^{2} \mathrm{H} 2 ;$ $\mathrm{d} 3, \mathrm{G}^{2} \mathrm{~N} 1 \mathrm{H} \rightarrow \mathrm{G}^{3} N^{2} \mathrm{H} 1 ; \mathrm{d} 4, \mathrm{G}^{2} \mathrm{~N} 1 \mathrm{H} \rightarrow \mathrm{G}^{3} N^{2} \mathrm{H} 2 ; \mathrm{e} 1, \mathrm{~T}^{17} \mathrm{~N} 3 \mathrm{H} \rightarrow \mathrm{X}^{6} \mathrm{H} 2 ; \mathrm{e} 2, \mathrm{~T}^{17} \mathrm{~N} 3 \mathrm{H} \rightarrow \mathrm{Y}^{7}$ $\mathrm{H} 2 ; \mathrm{f} 1, \mathrm{~T}^{19} \mathrm{~N} 3 \mathrm{H} \rightarrow \mathrm{A}^{4} \mathrm{H} 2 ; \mathrm{f} 2, \mathrm{~T}^{19} \mathrm{~N} 3 \mathrm{H} \rightarrow \mathrm{G}^{3} N^{2} \mathrm{H} 1 ; \mathrm{f} 3, \mathrm{~T}^{19} \mathrm{~N} 3 \mathrm{H} \rightarrow \mathrm{G}^{18} N^{2} \mathrm{H} 1 ; \mathrm{f} 4, \mathrm{~T}^{19}$ $\mathrm{N} 3 \mathrm{H} \rightarrow \mathrm{G}^{18} N^{2} \mathrm{H} 2 ; \mathrm{g} 1, \mathrm{~T}^{14} \mathrm{~N} 3 \mathrm{H} \rightarrow \mathrm{A}^{9} \mathrm{H} 2 ; \mathrm{g} 2, \mathrm{~T}^{14} \mathrm{~N} 3 \mathrm{H} \rightarrow \mathrm{A}^{10} \mathrm{H} 2 ; \mathrm{g} 3, \mathrm{~T}^{14} \mathrm{~N} 3 \mathrm{H} \rightarrow \mathrm{G}^{8} N^{2} \mathrm{H} 1 ; \mathrm{g} 4$, $\mathrm{T}^{14} \mathrm{~N} 3 \mathrm{H} \rightarrow \mathrm{G}^{8} N^{2} \mathrm{H} 2 ; \mathrm{h} 1, \mathrm{~T}^{16} \mathrm{~N} 3 \mathrm{H} \rightarrow \mathrm{Y}^{7} \mathrm{H} 2 ; \mathrm{i} 1, \mathrm{~T}^{13} \mathrm{~N} 3 \mathrm{H} \rightarrow \mathrm{A}^{10} \mathrm{H} 2$. The experiment was carried out at $10^{\circ} \mathrm{C}$. 


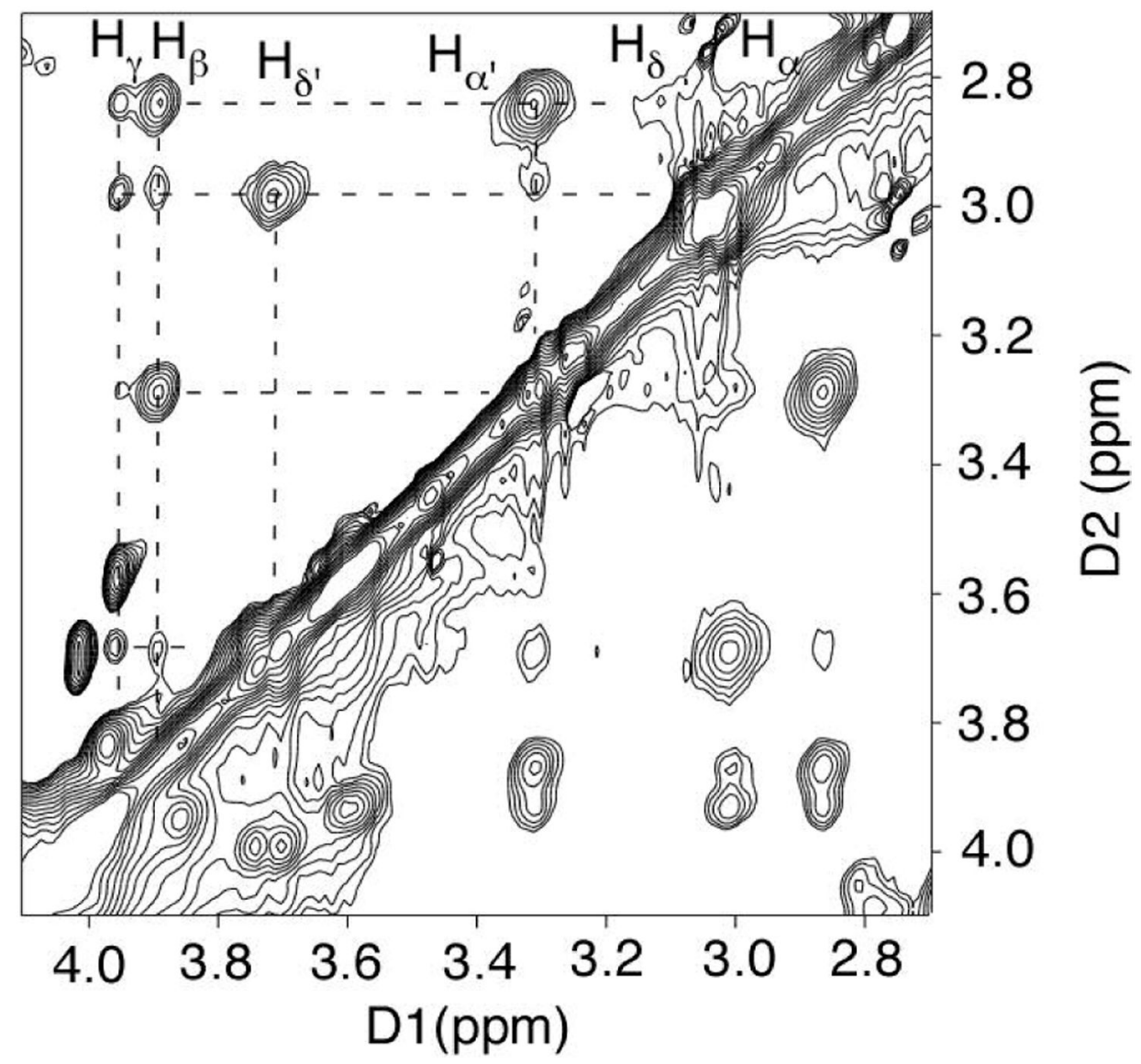

Figure 3.

Expanded NOESY spectrum showing the assignments for the butadiene protons in the (S,S)BD-(61-2,3) duplex. The experiment was carried out at at $250 \mathrm{~ms}$ mixing time and $800 \mathrm{MHz}$. The temperature was $25^{\circ} \mathrm{C}$. 


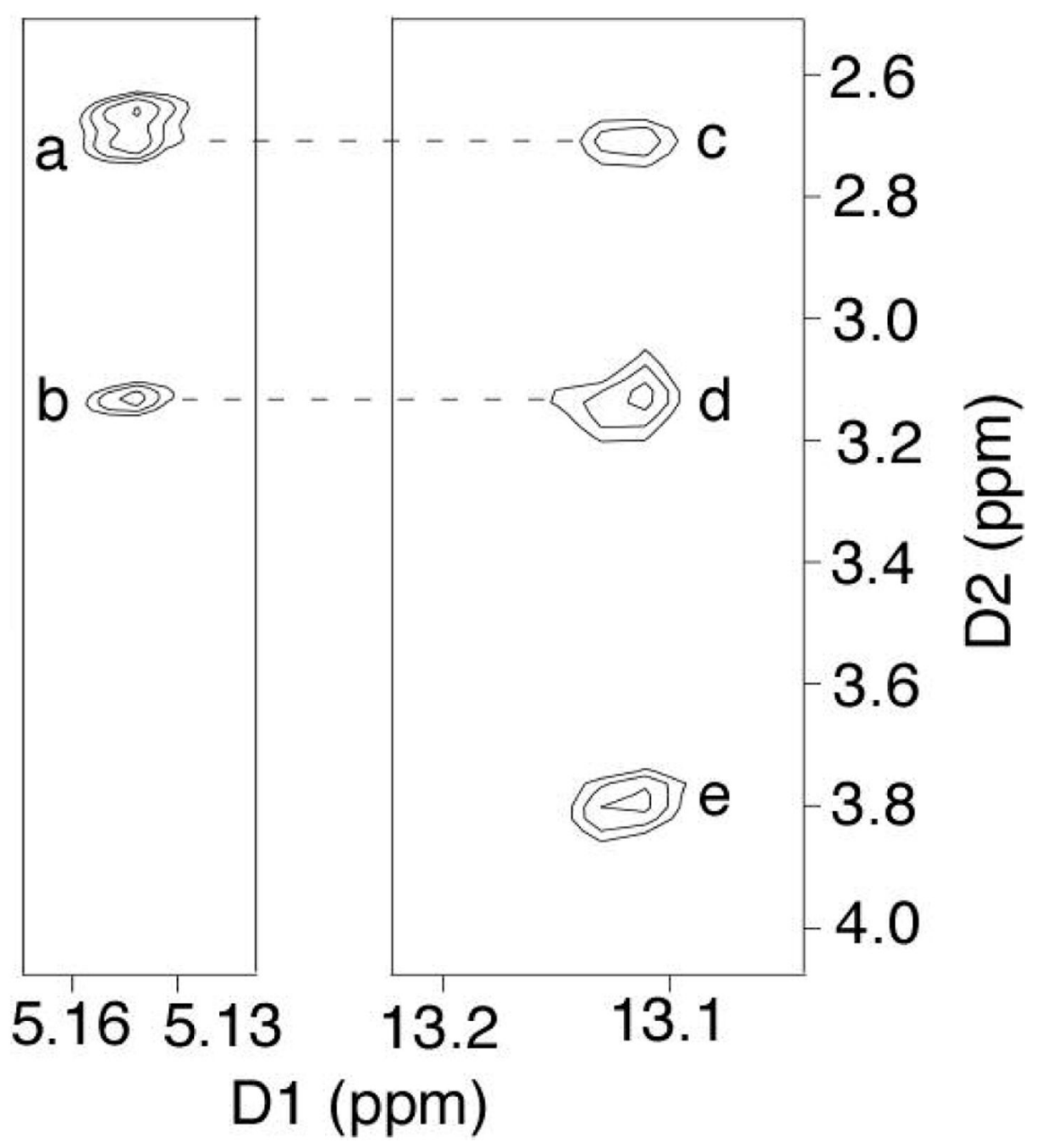

Figure 4.

Tile plot showing NOE cross-peaks between BD and DNA of the (S,S)-BD-(61-2,3) crosslinked duplex. Cross-peaks a, $\mathrm{C}^{5} \mathrm{H} 5 \rightarrow \mathrm{BD} \mathrm{H}_{\alpha} ; \mathrm{b}, \mathrm{C}^{5} \mathrm{H} 5 \rightarrow \mathrm{BD} \mathrm{H}_{\alpha^{\prime}} ; \mathrm{c}, \mathrm{T}^{17} \mathrm{~N} 3 \mathrm{H} \rightarrow \mathrm{BD} \mathrm{H}_{\alpha}$; $\mathrm{d}, \mathrm{T}^{17} \mathrm{~N} 3 \mathrm{H} \rightarrow \mathrm{BD} \mathrm{H}^{\alpha} ; \mathrm{e}, \mathrm{T}^{17} \mathrm{~N} 3 \mathrm{H} \rightarrow \mathrm{BD} \mathrm{H}_{\beta}$. The experiment was at $250 \mathrm{~ms}$ mixing time and $800 \mathrm{MHz}$. 
A

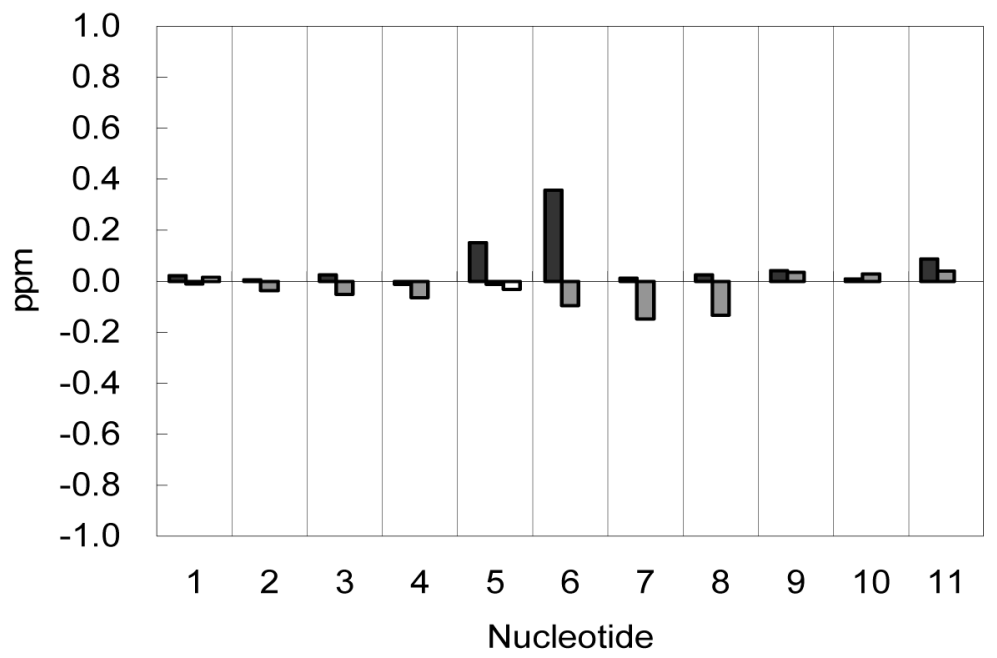

B

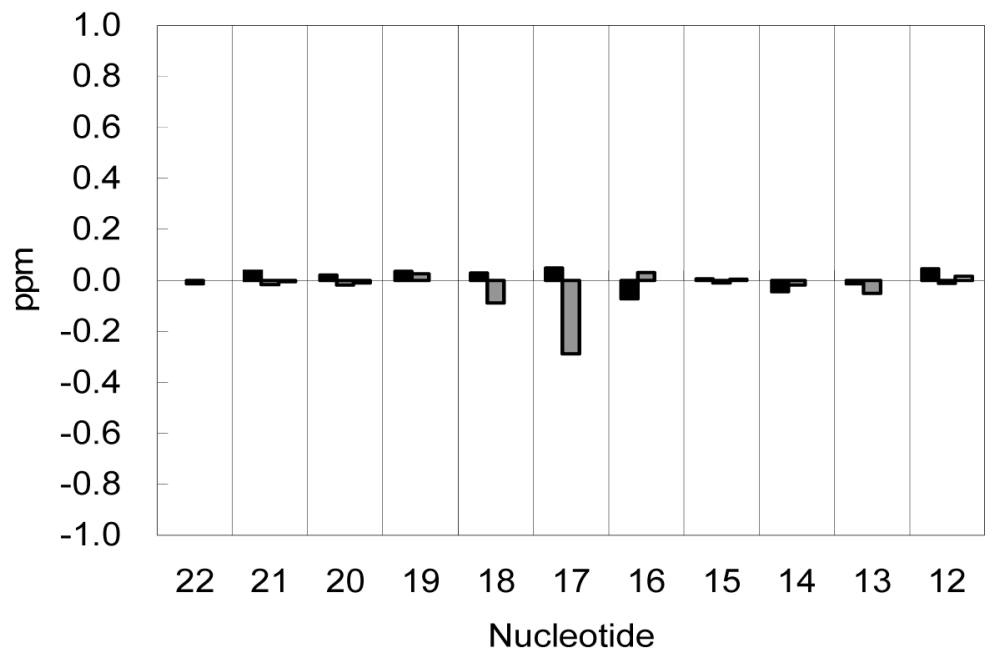

Figure 5.

Chemical shift differences of protons of the $(S, S)$-BD-(61-2,3) cross-linked adduct duplex relative to the unmodified ras61 onligodeoxynucleotide. A. Nucleotides $\mathrm{C}^{1} \rightarrow \mathrm{G}^{11}$ of the $(S, S)$-BD-(61-2,3) cross-linked duplex. B. Nucleotides $\mathrm{C}^{12} \rightarrow \mathrm{G}^{22}$ of the (S,S)-BD-(61-2,3) cross-linked duplex. Black bars represents the deoxyribose $\mathrm{H1}^{\prime}$ protons; gray bars represent the purine $\mathrm{H} 8$ or pyrimidine $\mathrm{H} 6$ protons, respectively; white bars represent the cytosine $\mathrm{H} 5$ protons. 

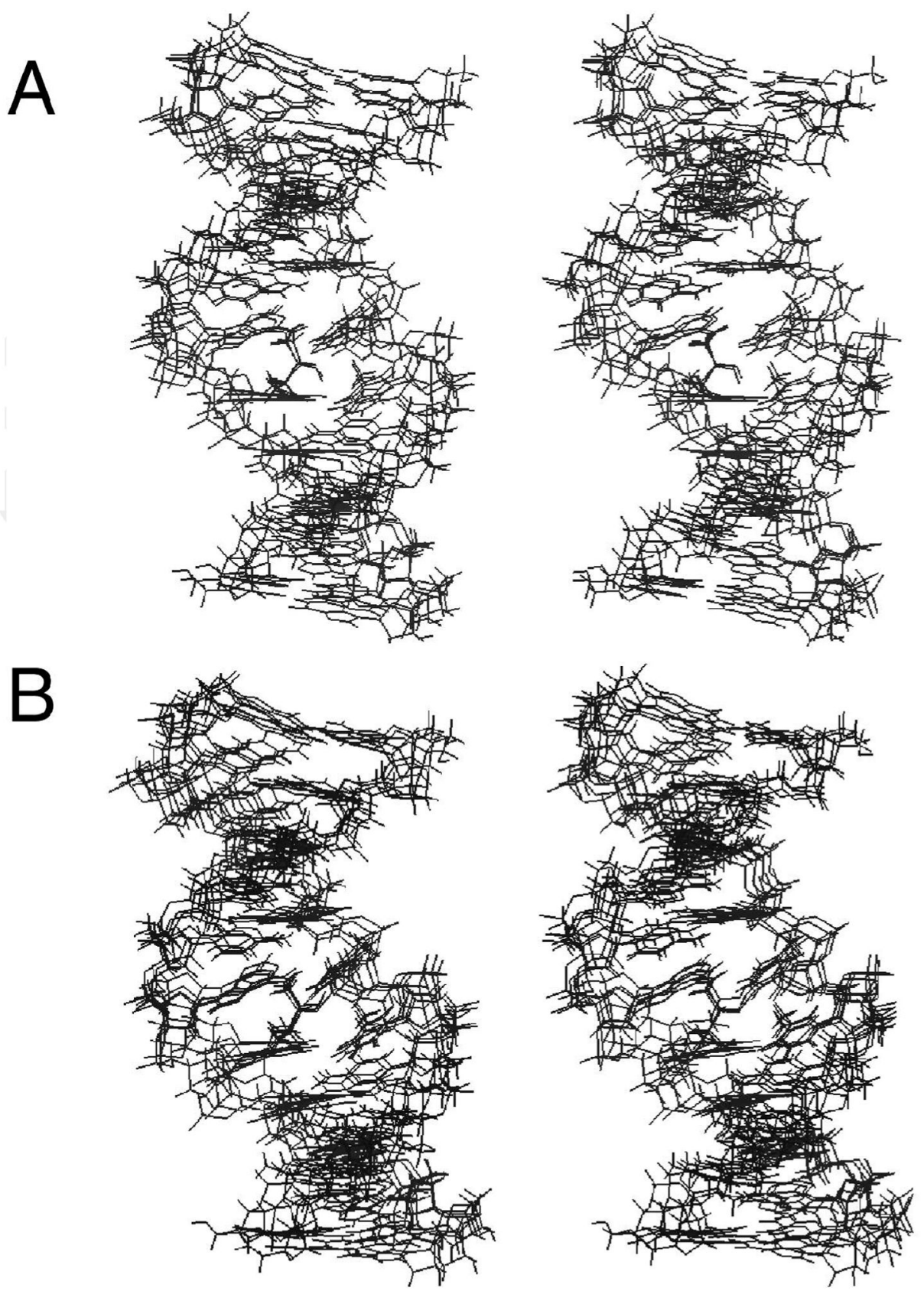

Figure 6.

A. Stereoview of superimposed conformation I structures of the (S,S)-BD-(61-2,3) cross-linked duplex emergent from the simulated annealing rMD protocol. B. Stereoview of superimposed conformation II structures of the $(S, S)$-BD-(61-2,3) cross-linked duplex emergent from the simulated annealing rMD protocol. The structures resulted from randomly seeded calculations. 
A1

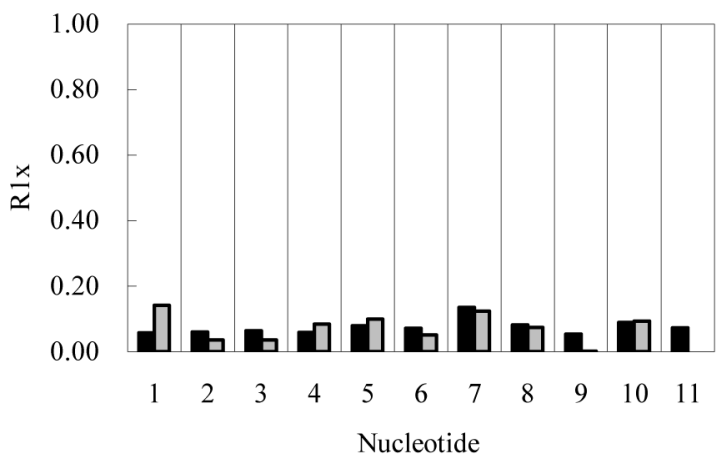

A2

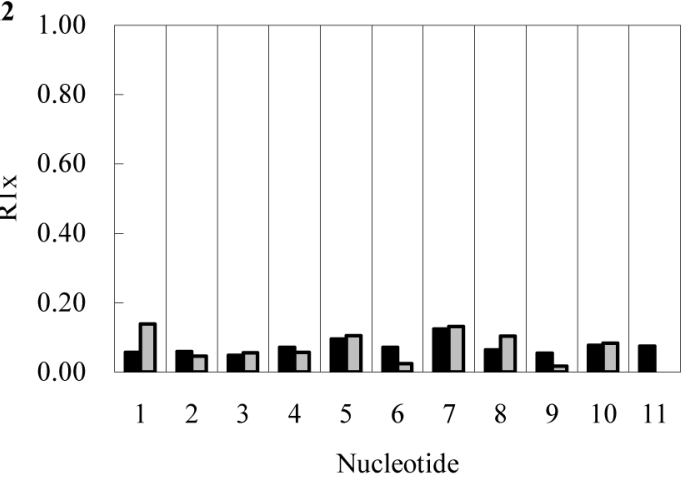

B1
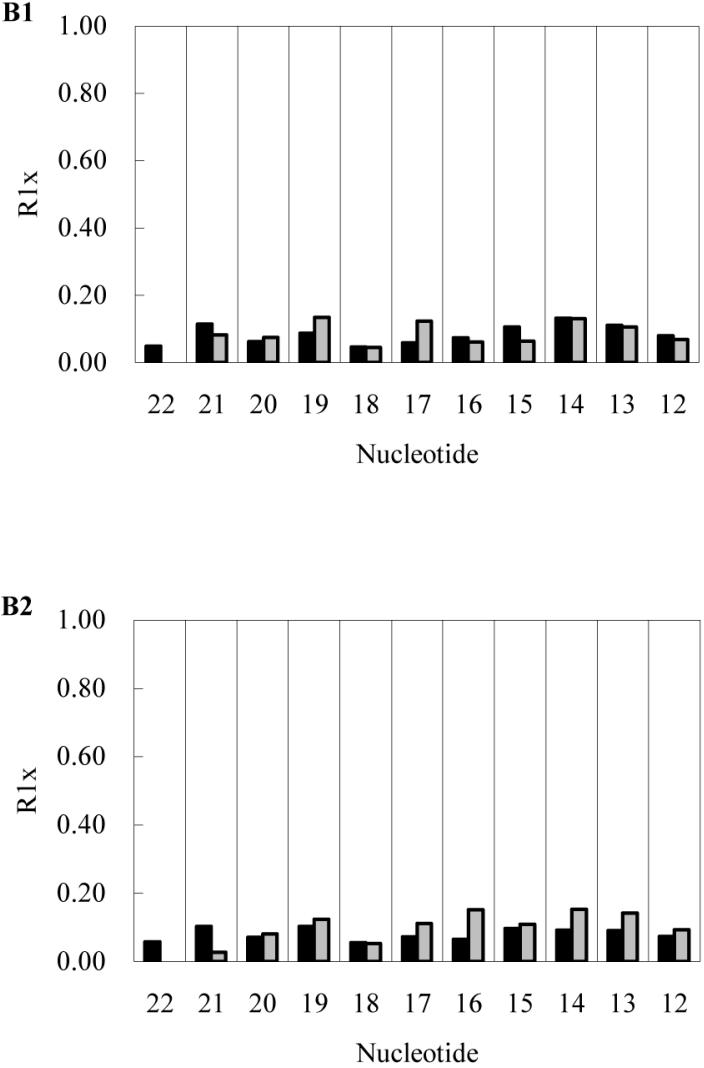

Figure 7.

Sixth root residuals between calculated NOE intensities and experimental NOE intensities $\left(\mathrm{R}_{1}{ }^{\mathrm{x}}\right.$ values) as a function of position in the $(S, S)$-BD-(61-2,3) adduct. A. Nucleotides $\mathrm{C}^{1} \rightarrow$ $\mathrm{G}^{11}$ of conformation I with hydrogen bonding between $\beta-\mathrm{OH}$ and $\mathrm{T}^{16} O^{4}$. B. Nucleotides $\mathrm{C}^{12} \rightarrow \mathrm{G}^{22}$ of conformation I. C. Nucleotides $\mathrm{C}^{1} \rightarrow \mathrm{G}^{11}$ of conformation II with hydrogen bonding between $\beta$-OH and $\mathrm{T}^{17} O^{4}$. D. Nucleotides $\mathrm{C}^{12} \rightarrow \mathrm{G}^{22}$ of conformation II. 


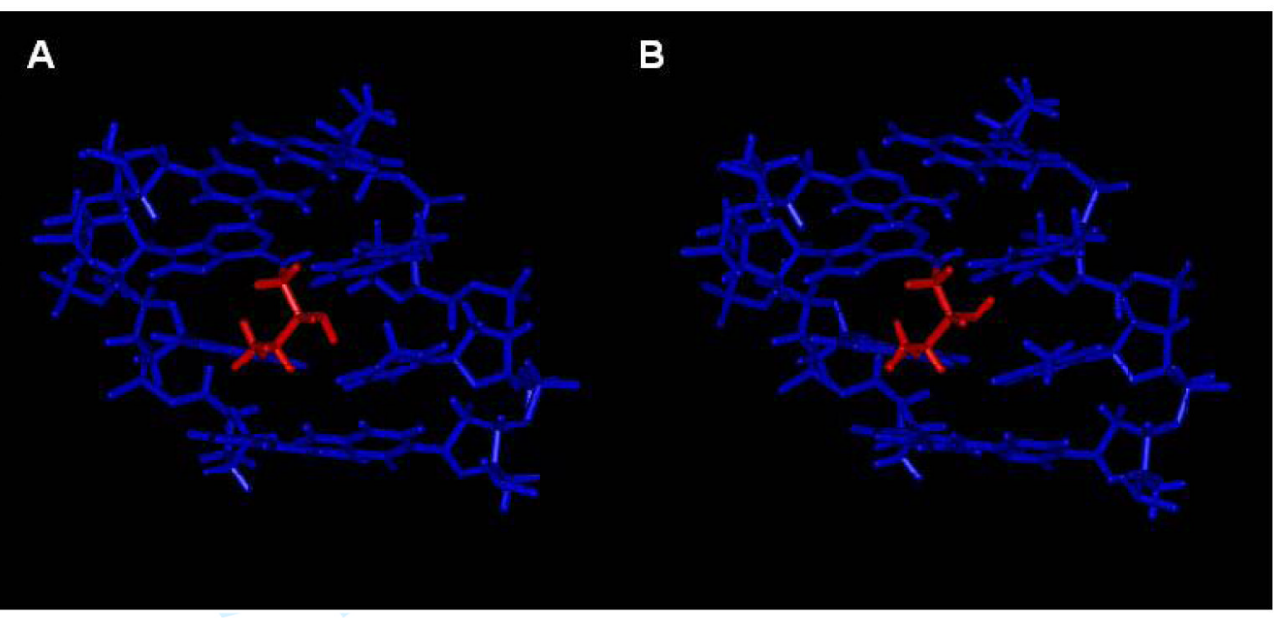

Figure 8.

Stick models of the (S,S)-BD-(61-2,3) cross-linked duplex predicted by rMD calculations. A. Conformation I with hydrogen bonding between $\beta-\mathrm{OH}$ and $\mathrm{T}^{17} \mathrm{O}^{4}$. B. Conformation II with hydrogen bonding between $\beta-\mathrm{OH}$ and $\mathrm{T}^{16} \mathrm{O}^{4}$. The butadiene moiety is in red. 


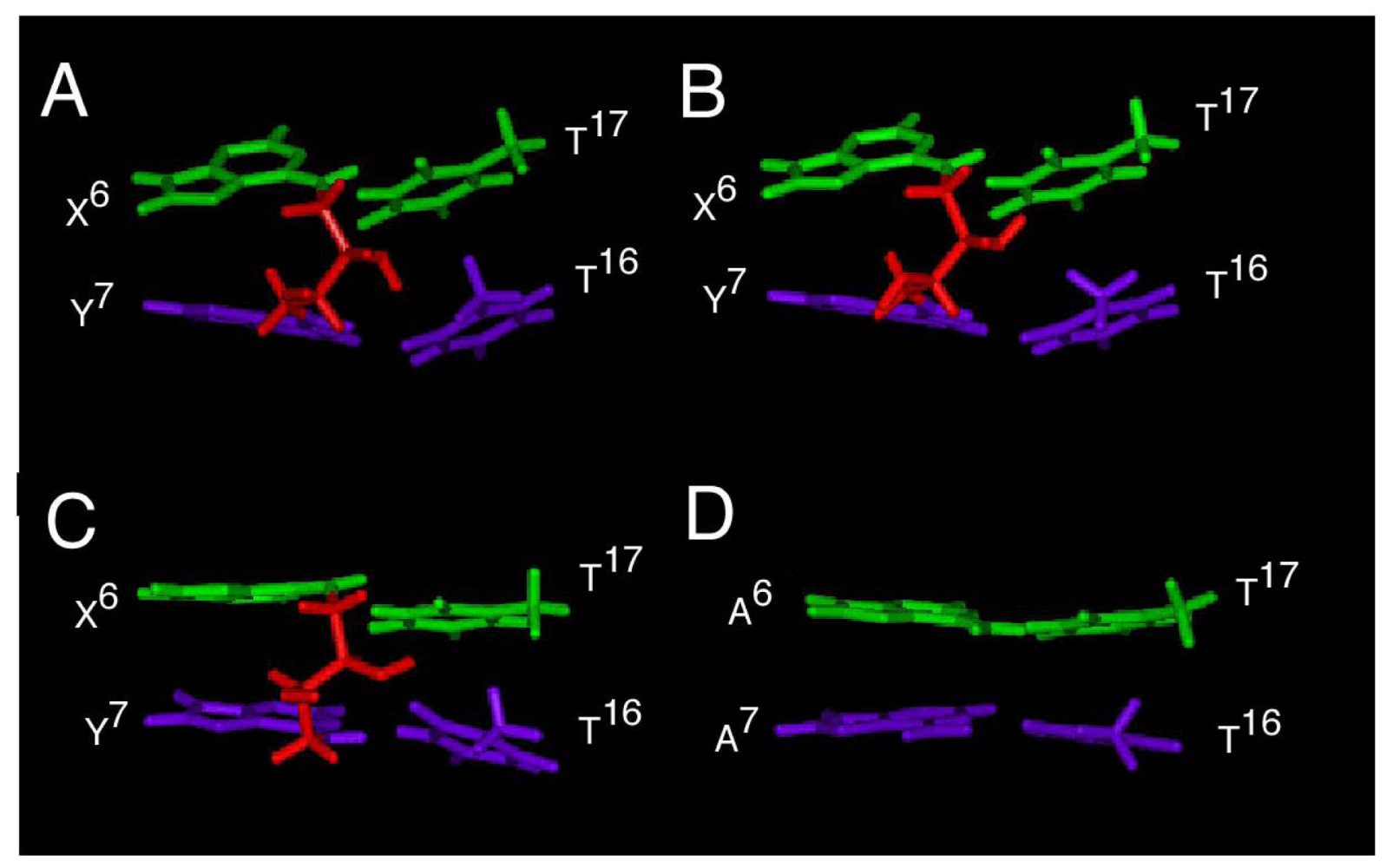

Figure 9.

Views from the major groove of the duplex DNA of the $(S, S)$-BD- $(61-2,3)$ and the $(R, R)-\mathrm{BD}$ (61-2,3) cross-linked adduct duplexes at the lesion site predicted by rMD calculations, as compared to the unmodified ras61 oligodeoxynucleotide duplex. A. Conformation I of the $(S, S)$-BD-(61-2,3) cross-linked duplex detailing base pairs $\mathrm{X}^{6} \cdot \mathrm{T}^{17}$ (green) and $\mathrm{Y}^{7} \cdot \mathrm{T}^{16}$ (purple). B. Conformation II of the $(S, S)$-BD-(61-2,3) cross-linked duplex detailing base pairs $\mathrm{X}^{6} \cdot \mathrm{T}^{17}$ (green) and $\mathrm{Y}^{7} \cdot \mathrm{T}^{16}$ (purple). C. The $(R, R)$-BD-(61-2,3) cross-linked duplex detailing base pairs $\mathrm{X}^{6} \cdot \mathrm{T}^{17}$ (green) and $\mathrm{Y}^{7} \cdot \mathrm{T}^{16}$ (purple). D. The unmodified ras61 duplex detailing base pairs $\mathrm{A}^{6} \cdot \mathrm{T}^{17}$ (green) and $\mathrm{A}^{7} \cdot \mathrm{T}^{16}$ (purple). The butadiene moiety is in red. 


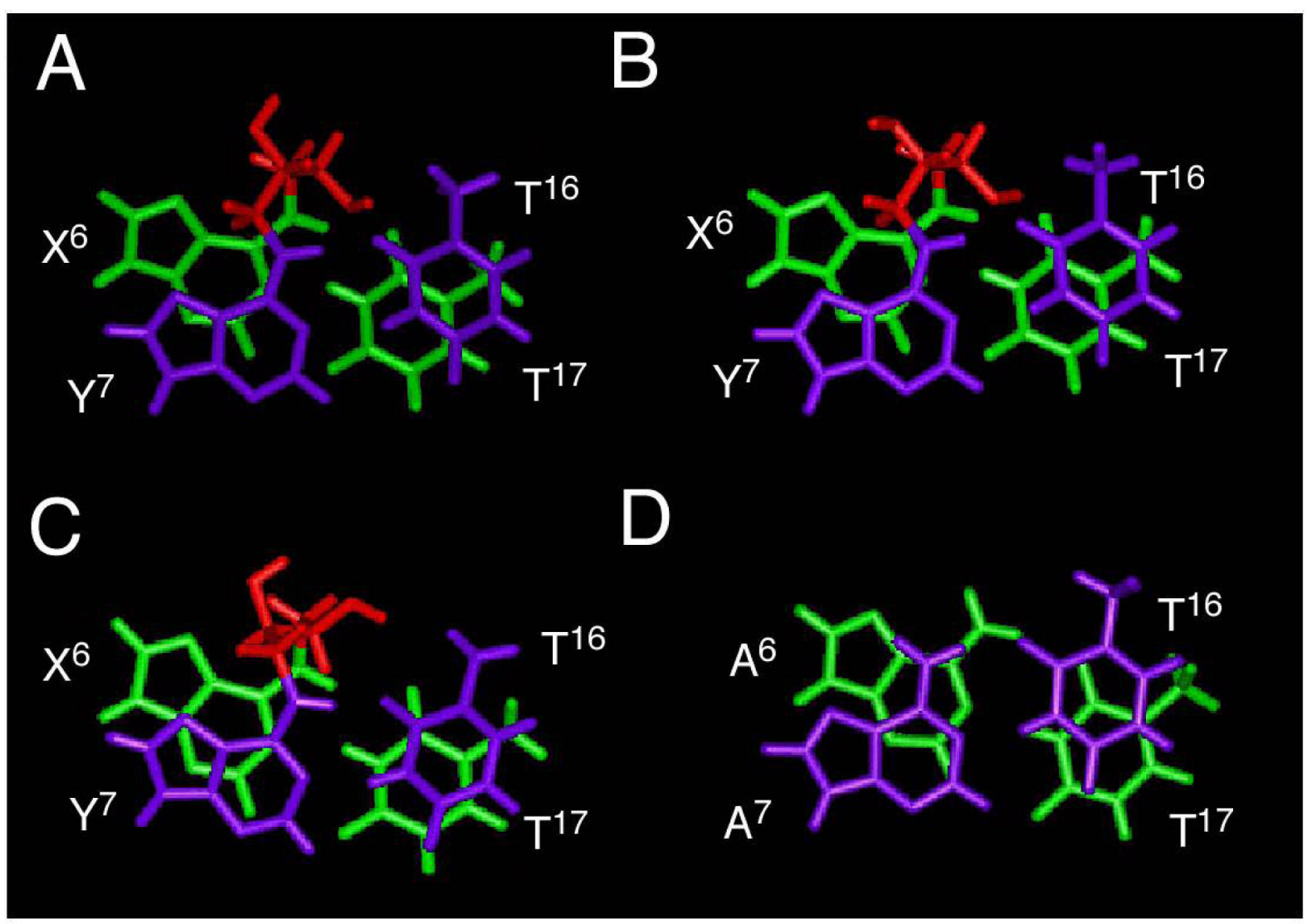

Figure 10.

Base stacking of the $(S, S)$-BD-(61-2,3) and the $(R, R)$-BD-(61-2,3) cross-linked duplexes at the lesion site predicted by rMD calculations, as compared to the unmodified ras61 duplex. A. Conformation I of the $(S, S)$-BD-(61-2,3) cross-linked duplex detailing stacking of the base pairs $\mathrm{X}^{6} \cdot \mathrm{T}^{17}$ (green) and $\mathrm{Y}^{7} \cdot \mathrm{T}^{16}$ (purple). B. Conformation II of the $(S, S)$-BD-(61-2,3) crosslinked duplex detailing stacking of the base pairs $\mathrm{X}^{6} \cdot \mathrm{T}^{17}$ (green) and $\mathrm{Y}^{7} \cdot \mathrm{T}^{16}$ (purple). C. The $(R, R)$-BD-(61-2,3) cross-linked duplex detailing stacking of the base pairs $\mathrm{X}^{6} \cdot \mathrm{T}^{17}$ (green) and $\mathrm{Y}^{7} \cdot \mathrm{T}^{16}$ (purple). D. The unmodified ras61 duplex detailing stacking of the base pairs $\mathrm{A}^{6} \cdot \mathrm{T}^{17}$ (green) and $\mathrm{A}^{7} \cdot \mathrm{T}^{16}$ (purple). The butadiene moiety is in red. 


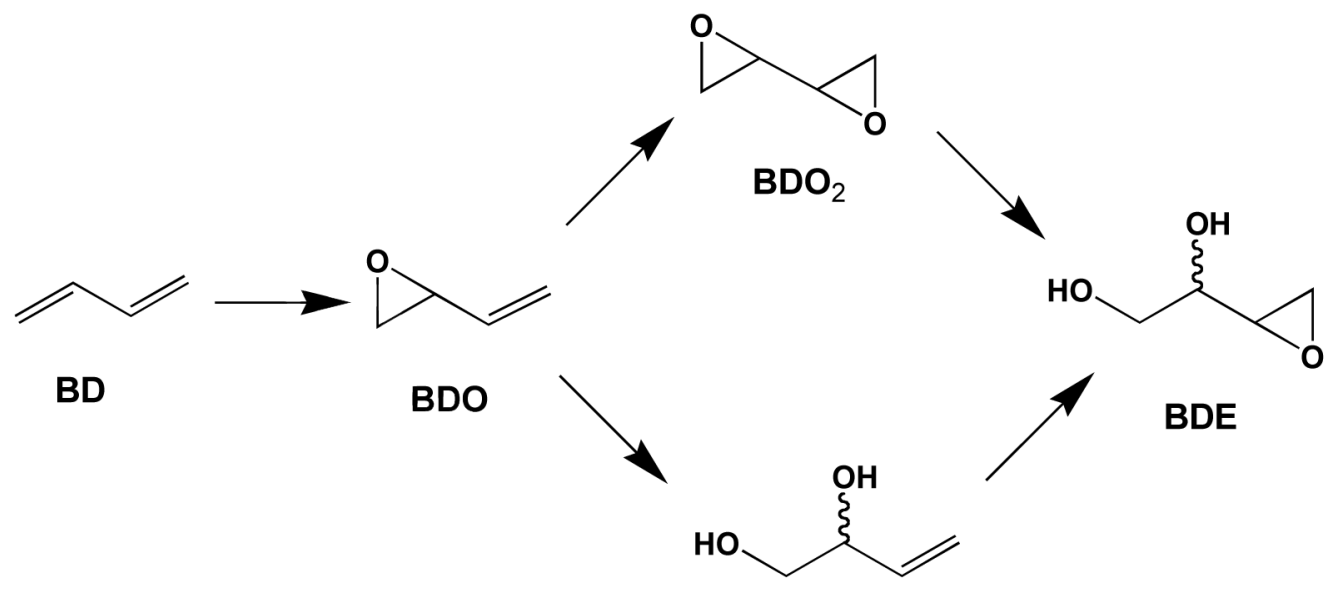

Scheme 1.

Reactive Metabolites of Butadiene. 
A.

$$
\begin{gathered}
\underline{60} \quad \underline{61} \quad \underline{62} \\
5^{\prime}-C^{1}\left|G^{2} G^{3} A^{4}\right| C^{5} X^{6} Y^{7}\left|G^{8} A^{9} A^{10}\right| G^{11}-3^{\prime} \\
3^{\prime}-G^{22}\left|C^{21} C^{20} T^{19}\right| G^{18} T^{17} T^{16}\left|C^{15} T^{14} T^{13}\right| C^{12}-5^{\prime}
\end{gathered}
$$

B.<smiles>[R]n1cnc2c(NC[C@H](O)[C@H](O)CNc3ncnc4c3ncn4[R])ncnc21</smiles>

Scheme 2.

The ras61 oligodeoxynucleotide (A), and the chemical structure of (B) the $(2 S, 3 S)-\mathrm{N}^{6}-(2,3-$ dihydroxybutyl)-2-deoxyadenosyl cross-linked adduct and nomenclature. 
Table 1

Analysis of the rMD-Generated Structures of the ras61 $(S, S) N^{6}, N^{6}$-dA Cross-Linked Adduct.

\begin{tabular}{ll}
\hline NMR restraints & 413 \\
total no. of distance restraints & 69 \\
$\quad$ interresidue distance restraints & 339 \\
$\quad$ intraresidue distance restraints & 5 \\
$\quad$ DNA-cross-link distance restraints & 39 \\
empirical restraints & 90 \\
H-bonding restraints & 104 \\
sugar pucker restraints & \\
backbone torsion angle restraints & \\
Structural statistics & \\
NMR R-factor $\left(\mathrm{R}_{1}^{\mathrm{x}}\right)$ a,b,c & $0.0903 \pm 0.0140$ \\
$\quad$ <rMDIi> & $0.0848 \pm 0.0142$ \\
$\quad$ <MDIj> & 0.0200 \\
rmsdI of NOE violations $(\AA)$ & 0.0195 \\
rmsdII of NOE violations $(\AA)$ & $0.553 \pm 0.13$ \\
pairwise rmsd $(\AA)$ over all atoms & \\
<MDIi> vs <rMDIav> & \\
<MDIIj> vs <rMDIIav> & $0.559 \pm 0.17$
\end{tabular}

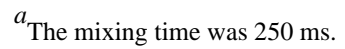

${ }^{b} \mathrm{R}_{1} \mathrm{x}=\Sigma\left|\left(\mathrm{a}_{\mathrm{O}}\right) \mathrm{i}^{1 / 6}-\left(\mathrm{a}_{\mathrm{c}}\right)_{\mathrm{i}}{ }^{1 / 6}\right| / \Sigma\left|\left(\mathrm{a}_{\mathrm{O}}\right) \mathrm{i}^{1 / 6}\right|$, where $\mathrm{a}_{\mathrm{O}}$ and $\mathrm{a}_{\mathrm{c}}$ are the intensities of observed (non-zero) and calculated NOE cross-peaks.

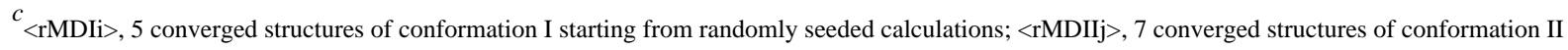
starting from randomly seeded calculations; <rMDIav>, average of 5 converged structures of conformation I; <rMDIIav>, average of 7 converged structures of conformation II; rmsdI, rmsd of conformation I; rmsdII, rmsd of conformation II. 